\title{
DOCTRINA DEL TRIBUNAL CONSTITUCIONAL DURANTE EL PRIMER CUATRIMESTRE DE 2016
}

Doctrine of the Constitutional Court during the First Four-Month Period of 2016

\author{
JUAN LUIS REQUEJO PAGÉS \\ JUAN CARLOS DUQUE VILLANUEVA \\ CARLOS ORTEGA CARBALLO \\ MARIAN AHUMADA RUIZ
}


I. JURISDICCIÓN CONSTITUCIONAL. DERECHO PROCESAL CONSTITUCIONAL. II. FUENTES DEL DERECHO. III. ESTRUCTURA TERRITORIAL DEL ESTADO. IV. ORGANIZACIÓN TERRITORIAL DEL ESTADO. V. DERECHOS FUNDAMENTALES.

\section{JURISDICCIÓN CONSTITUCIONAL. DERECHO PROCESAL CONSTITUCIONAL}

1. La condición de la trascendencia constitucional de las demandas de amparo parece haber sido ya suficientemente aquilatada por el Tribunal Constitucional (TC) en los años que han seguido a la reforma de 2007 como para que sean cada vez menos las novedades reseñables al respecto. Por lo que hace al primer cuatrimestre del año, nada nuevo cabe añadir a lo que ya se sabe sobre el entendimiento de aquel concepto por parte del TC, cuyas secciones se atienen estrictamente al principio de que el juicio sobre la existencia de la lesión del derecho debe preceder al examen de la trascendencia constitucional de la demanda ${ }^{1}$ y admiten la eventualidad de la admisión de recursos de amparo sustancialmente idénticos ${ }^{2}$, dos soluciones cuyo efecto combinado se traduce en la disolución del nuevo requisito de la trascendencia en la vieja categoría del contenido constitucional de la demanda ${ }^{3}$.

Fuera de la intuición de que en este viaje de regreso ha quedado por el camino, no ya la pretendida objetivación del recurso de amparo, sino la objetividad misma de las condiciones de admisibilidad de las demandas que lo instrumentan, poco más puede destacarse. Si se quiere, la constatación de que no son tan excepcionales como cabría esperar los supuestos de inobservancia de la jurisprudencia constitucional por parte de los tribunales ordinarios — con la

1 Así, ATC 27/2016 (Sección Segunda), de 8 de febrero, y ATC 28/2016 (Sección Cuarta), de 9 de febrero.

2 Por ejemplo, ATC 24/2016 (Sección Segunda), de 4 de febrero, y ATC 44/2016 (sección Segunda), de 22 de febrero. También, STC 48/2016 (Sala Primera), de 14 de marzo (FJ 2).

3 Pueden verse, en este sentido, las crónicas publicadas en REDC, núm. 88, 2010, pp. 312-314, y en REDC, núm. 102 (2014), pp. 256-259. 
consiguiente trascendencia de los recursos que los denuncian-, si bien tampoco puede hablarse de un problema de alcance general, pues, como tantas veces en el pasado, en esta ocasión el motivo de discordia ha vuelto a ser la doctrina sobre la prescripción penal sentada en la STC 63/2005 (Sala Segunda), de 14 de marzo, reiterada una vez más en la STC 51/2016 (Sala Primera), de 14 de marzo ${ }^{4}$. Supuesto al que puede añadirse el de la insistencia de los Juzgados de lo Contencioso-Administrativo de Madrid en acordar señalamientos con demoras de varios años en los procedimientos abreviados de extranjería, obviando de ese modo reiterados pronunciamientos estimatorios de demandas de amparo por infracción del derecho a un proceso sin dilaciones indebidas, como han hecho de nuevo las SSTC 63/2016 (Sala Segunda), de 11 de abril, y 75 a 77/2016 (Sala Segunda), de 25 de abril, Sentencias que, por las razones que a continuación se exponen, también merecen subrayarse.

2. En efecto, la solución que en ellas se adopta en relación con el requisito del agotamiento de la vía judicial previa al amparo no deja de suscitar algún reparo de principio. Situado ante la alternativa de dar por agotada la vía judicial, según resultaba sin lugar a duda de la norma procesal aplicable al caso, o interponer el recurso de revisión indicado en la resolución litigiosa, la Sala Segunda afirma que al demandante de amparo «no le quedaba otra vía que acudir directamente ante este Tribunal Constitucional» (STC 63/2016, FJ 3). Se olvida con ello que ya desde la STC 241/2006 (Pleno), de 20 de julio, no puede

considerarse como manifiestamente improcedente a los efectos de determinar la extemporaneidad del recurso de amparo la interposición por el demandante [...], cuente o no con asistencia letrada, de recursos o remedios procesales objetiva y manifiestamente improcedentes cuando la misma sea consecuencia de una errónea indicación consignada en la instrucción de recursos a que se refiere el art. 248.4 LOPJ (STC 241/2006, FJ 3) 5 .

4 Se ha dado cuenta en varias crónicas de los distintos episodios de contestación a esa doctrina del TC: REDC, núm. 83, 2008, pp. 216-218; REDC, núm. 87, 2009, p. 290; $R E D C$, núm. 88, 2010, p. 316; $R E D C$, núm. 91, 2011, pp. 286-287, y $R E D C$, núm. 93, 2011, pp. 261-262.

5 Comentada en la crónica publicada en $R E D C$, núm. 78, 2006, pp. 235-236, en la que concluíamos que, «[a]nte semejante disyuntiva, el Abogado podrá optar por agotar el remedio sugerido por el órgano judicial o por interponer inmediatamente el recurso de amparo, sin que en el primer caso la improcedencia objetiva del remedio pueda redundar después en la extemporaneidad de la demanda». 
Por lo demás, el precepto que excluía la posibilidad del recurso ofrecido al demandante había sido declarado, justamente por eso, contrario a la Constitu-

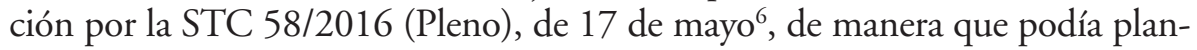
tearse la duda acerca de la posible concurrencia sobrevenida de la falta de agotamiento de la vía judicial. Posibilidad descartada por el TC en razón de la fecha en la que se había declarado la inconstitucionalidad del precepto en cuestión, sin que a su juicio fuera tampoco posible retrotraer las actuaciones para que el actor pudiera interponer el recurso de revisión vedado por aquel, ya que con ello solo se añadirían nuevas dilaciones a las ya padecidas y se anularía además la sentencia estimatoria con la que finalmente había concluido el proceso a quo.

3. A propósito del control jurisdiccional de las resoluciones de declaración y de prórroga del estado de alarma, la STC 83/2016 (Pleno), de 28 de abril ${ }^{7}$, confirma - esta vez sin votos discrepantes - la posición mantenida en el ATC 7/2012 (Pleno), de 13 de enero ${ }^{8}$, si bien ahora se incluye también la declaración de aquel estado entre las resoluciones que, por disfrutar de una «legalidad excepcional» (STC 83/2016, FJ 10) a pesar de formalizarse mediante decreto, únicamente pueden ser impugnadas a través de los procesos constitucionales de control de las leyes, disposiciones y actos con fuerza o valor de ley, sin perjuicio de su eventual impugnación indirecta con ocasión del control judicial de sus actos de aplicación. Se salva de este modo una de las críticas esgrimidas en el voto particular al ATC 7/2012, pues entonces el Pleno, seguramente por inadvertencia, al enumerar los actos y decisiones que no pueden ser objeto de una demanda de amparo por tener «valor de ley», se refería solo a uno de los adoptados por el Gobierno (la declaración del estado de excepción), olvidando la declaración del estado de alarma, que también es de su competencia.

4. Sobre el trámite conciliatorio establecido en el art. 33.2 LOTC y su función delimitadora del contenido de un eventual recurso de inconstitucionalidad se ha pronunciado la STC 82/2016 (Pleno), de 28 de abril. Lo ha hecho en términos un tanto discutibles, pues parte de la base de que aquel precepto exige la «identificación de los preceptos conflictivos» [STC 82/2016, FJ 2, a)], cuando el art. 33.2 LOTC solo habla de «un acuerdo sobre iniciación de negociaciones» y de que se pueda «instar, en su caso, la modificación del texto normativo» [art. 33.2, b) LOTC]. «Texto normativo» que no puede

\footnotetext{
Reseñada infra, pp. 325-327.

Vid. infra, pp. 295-297.

8 Comentado en $R E D C$, núm. 95, 2012, pp. 263-265; y REDC, núm. 96, 2012, pp. 235-236.
} 
ser sino el de las «leyes, disposiciones o actos con fuerza de ley» a que se refiere el primer párrafo del propio art. 33.2 LOTC, es decir, la norma en su conjunto y no algunos de sus preceptos en particular.

Al comentar en su día el ATC 156/2008 (Pleno), de 12 de junio9, señalaba que el problema procesal planteado entonces (con ocasión de un incidente sobre el mantenimiento de la suspensión de una ley autonómica) podía traer causa de una identificación discutible entre el art. 33.2 y el art. 63.3 LOTC, pues mientras este último exige que en el requerimiento previo de incompetencia se especifiquen "con claridad los preceptos de la disposición o los puntos concretos de la resolución o acto viciados de incompetencia», aquel se refiere a la interposición del recurso "contra leyes, disposiciones o actos con fuerza de ley, en relación con los cuales, se cumplan los siguientes requisitos», entre los que no figura ningún trámite en el que se hayan de identificar expresamente los preceptos acaso impugnables, sino solo el deber de alcanzar «un acuerdo sobre iniciación de negociaciones para resolver las discrepancias». Si en el caso del art. 63 LOTC se está ante un conflicto estrictamente jurídico, en el del art. 33.2 LOTC es notoria la naturaleza política del debate entre las partes, toda vez que el precepto habla expresamente de «negociaciones». Una vez descartada la solución política negociada, el recurso de inconstitucionalidad traduciría en términos de Derecho el sentido de aquella discrepancia, siendo ése el momento para identificar los preceptos jurídicamente controvertidos. Por lo demás, las cosas pueden ser muy distintas según sean uno o varios los objetos de la ley (típicamente, una ley de acompañamiento). Si el acuerdo de negociación se limita a uno de los varios objetos de la ley, la prórroga del art. 33.2 LOTC solo podría aplicarse a los preceptos referidos a ese objeto, pero no a los restantes. La delimitación habría de hacerse por relación a objetos o materias, no por referencia a preceptos con abstracción de su contenido.

En el caso de la STC 82/2016 el Pleno se ha atenido a la identificación de los preceptos conflictivos señalados en el propio acuerdo de la Comisión bilateral, lo que le ha llevado a circunscribir con ellos el objeto del recurso, inadmitiendo, por extemporáneas, las impugnaciones de otros artículos. Con todo, también los preceptos excluidos han seguido la suerte de los correctamente impugnados, pues el Tribunal terminará declarando la inconstitucionalidad de la disposición legal en su conjunto, "por conexión o consecuencia» (art. 39.1 LOTC) (STC 82/2016, FJ 7). Solución de la que discrepa en voto particular el magistrado Sr. Xiol Ríos, para quien la mayoría ha decretado la nulidad de los preceptos impugnados extemporáneamente «sin ni siquiera examinarlos» (voto particular, apartado 4).

9 Vid. REDC, núm. 84, 2008, pp. 230-232. 
5. En relación con la modificación sobrevenida del parámetro de constitucionalidad y su incidencia sobre la disposición enjuiciada, puede traerse a colación la STC 8/2016 (Pleno), de 21 de enero, en la que, tras concluirse que no era de advertir alteración alguna en el canon de constitucionalidad vigente al tiempo de iniciarse el proceso, se afirma que «esto no nos impide considerar, como elemento de análisis ${ }^{10}$, la legislación aprobada por el Estado en el ejercicio de [su] competencia exclusiva, en su versión vigente en el momento del enjuiciamiento» (STC 8/2016, FJ 2), pues de otro modo no podría garantizarse que el ejercicio de una competencia autonómica no redundara en el menoscabo de una competencia del Estado. La legislación sobrevenida no se erige, por tanto, en parámetro de constitucionalidad de la norma autonómica, sino en «un elemento añadido de análisis, a efectos ilustrativos o de referencia» (loc. ult. cit.).

Como en el caso del ATC 23/2013 (Pleno), de 29 de enero ${ }^{11}$, la STC 35/2016 (Pleno), de 3 de marzo, sostiene que la derogación de la norma legal de cobertura de la disposición reglamentaria objeto de recurso directo ante el Tribunal Supremo (TS), y la propia derogación de esta última, no ha de suponer necesariamente la desaparición del objeto de la cuestión de inconstitucionalidad planteada contra aquella norma legal. Ello solo sucederá si la norma reglamentaria no conserva ningún género de ultraactividad y la ley en cuestión no resulta ya aplicable en el proceso a quo, siendo de señalar que, en el supuesto del recurso directo contra reglamentos ante la jurisdicción contencioso-administrativa, la norma legal de contraste ha de ser la vigente en el momento de su planteamiento, no siendo en absoluto indiferente - por razón de sus efectos respectivos- que la desaparición de esta última traiga causa de su derogación o de su nulidad, lo que implica la subsistencia del objeto de la cuestión ${ }^{12}$ (STC 35/2016, FJ 2).

En fin, la STC 3/2016 (Sala Segunda), de 18 de enero, se atiene a la doctrina establecida en la STC 159/1997 (Pleno), de 2 de octubre, en el sentido de que la declaración de nulidad de una norma con rango de ley por razones ajenas a la infracción de derechos fundamentales no irradia sus efectos sobre las sentencias judiciales que la hayan aplicado; ni siquiera sobre las que hayan sido objeto de demandas de amparo promovidas tras haberse intentado en la vía previa el planteamiento judicial de una cuestión y admitidas a trámite antes de la declaración de inconstitucionalidad ${ }^{13}$. En el caso, la Sala Segunda

10 Cursiva añadida.

11 Comentado en REDC, núm. 98, 2013, p. 277.

12 Del mismo tenor es la STC 183/1997 (Sala Primera), de 28 de octubre.

13 Sobre esta doctrina pueden verse las crónicas publicadas en REDC, núm. 52, 1998, p. 151, y REDC, núm. 53, 1998, p. 206, número este en el que se incluye un comen- 
ha entendido que la declaración de nulidad por el TS de la norma foral que daba cobertura a las liquidaciones tributarias combatidas ante el TC mediante un recurso de amparo no afectaba a la pervivencia del objeto de este último. De un lado, porque el pronunciamiento del TS no permitía la revisión del proceso previo al amparo, concluido mediante sentencia con fuerza de cosa juzgada. De otro, precisamente por causa de la doctrina de la STC 159/1997.

6. La doctrina establecida en la STC 175/2001 (Pleno), de 26 de ju${ }_{1 i o^{14}}$, acerca de la legitimación de las personas jurídicas públicas para interponer recursos de amparo ha sido reiterada en la STC 44/2016 (Sala Segunda), de 14 de marzo, así como en las SSTC 22/2016 (Sala Segunda), de 15 de febrero $^{15}$, y 50/2016 (Sala Primera), de 14 de marzo; en estos dos últimos casos para sendos supuestos en los que el Ministerio Fiscal recurría en su doble condición de poder público lesionado en su derecho a la tutela judicial efectiva y de defensor del derecho fundamental de un particular [título este con el que también había recurrido, con carácter exclusivo, en el proceso que dio lugar a la STC 34/2016 (Sala Segunda), de 29 de febrero ${ }^{16}$ ].

En materia de legitimación es también de señalar la STC 27/2016, de 18 de febrero, en la que el Pleno excluye que una diputación provincial pueda plantear un conflicto en defensa de la autonomía local para denunciar una vulneración de intereses o competencias exclusivamente municipales, "como tampoco puede admitirse que, a la inversa, sean los municipios los que utilicen este cauce procesal para tratar de depurar una violación de una competencia estrictamente provincial» (STC 27/2016, FJ 4) ${ }^{17}$.

\section{FUENTES DEL DERECHO}

1. La resolución más relevante en lo que a este apartado de la crónica se refiere es, sin duda, la STC 83/2016 (Pleno), de 28 de abril ${ }^{18}$, que se pronuncia sobre el valor y rango de los reales decretos de declaración y prórroga del estado de alarma. La Sentencia resuelve el recurso de amparo promovido

tario de J. Urías Martínez: «Separación de procesos y tutela ante el Tribunal Constitucional» (pp. 267-281).

14 De la que se dio cuenta en $R E D C$, núm. 63, 2001, pp. 210-211.

15 Pueden verse los detalles infra, p. 314.

16 Comentada infra, pp. 314-316.

17 Juan Luis Requejo Pagés.

18 Reseñada supra, p. 292. 
por más de trescientos controladores aéreos contra los Autos de la Sala Tercera del TS que inadmitieron a trámite, por no resultar fiscalizables ante la jurisdicción contencioso-administrativa, los recursos interpuestos contra los Reales Decretos 1673/2010, de 4 de diciembre, y 1717/2010, de 17 de diciembre, por los que, respectivamente, se declaró y prorrogó el estado de alarma para la normalización del servicio público esencial del transporte aéreo.

Tras referirse el TC al modelo de regulación del derecho de excepción en el texto constitucional de 1978 (FJ 7) y, más detalladamente, a la del estado de alarma (FJ 8), considera trasladable y aplicable al presente supuesto la doctrina ya sentada en el ATC 12/2007 (Pleno), de 13 de enero ${ }^{19}$, en el que calificó como actos o decisiones parlamentarias con fuerza o valor de ley los actos de autorización de la prórroga del estado de alarma, de declaración y prorroga del estado de excepción y de declaración del estado de sitio (FJ 9).

Para el TC la declaración del estado de alarma es expresión del ejercicio de una competencia constitucional del Gobierno ex art. 116.1 CE, como órgano al que le corresponde la dirección política del Estado (art. $97 \mathrm{CE}$ ) y no en su condición de órgano superior de la Administración. Se trata, además, de una decisión de carácter normativo, «en cuanto establece el concreto estatuto jurídico del estado que se declara», que viene a integrar en cada caso, «sumándose a la Constitución y a la Ley Orgánica 4/1981, el sistema de fuentes del derecho de excepción, al complementar el derecho de excepción de aplicación en el concreto estado declarado», que puede llegar a desplazar «la legalidad ordinaria en vigor, en la medida en que viene a excepcionar, modificar o condicionar durante ese período la aplicabilidad de determinadas normas, entre las que pueden resultar afectadas leyes, normas o disposiciones con rango de ley, cuya aplicación puede suspender o desplazar». De manera que, aunque con la forma de Real Decreto del Consejo de Ministros, «la decisión de declarar el estado de alarma, dado su contenido normativo y efectos jurídicos, debe entenderse que queda configurada en nuestro ordenamiento como una decisión o disposición con rango de ley». E idéntica cualidad cabe predicar del real decreto por el que se prórroga el estado de alarma, el cual se configura, además, como «una formalización ad extra de la previa autorización del Congreso de los diputados», cuya condición de acto o decisión con rango o valor de ley se declaró en el ATC 7/2012 (FJ 10).

Dada la condición de decisiones o disposiciones con rango o valor de ley de la declaración gubernamental del estado de alarma y su prórroga, su fiscalización jurisdiccional corresponde al TC a través de los procesos constitucio-

19 Vid. las reseñas publicadas en $R E D C$, núm. 95, 2012, pp. 263-265 y 275-277; y REDC, núm. 96, 2012, pp. 235-236. 
nales de control de las leyes, disposiciones y actos con fuerza o valor de ley [arts. 161 y 163 CE y 27.2.b) LOTC], sin perjuicio de que los actos y disposiciones que puedan dictarse en su aplicación puedan impugnarse ante la jurisdicción ordinaria y los órganos judiciales, al enjuiciarlos, puedan promover cuestión de inconstitucionalidad contra los actos, decisiones o resoluciones con valor de ley de los que son aplicación. Asimismo, las personas afectadas podrán interponer recurso de amparo constitucional contra los actos y disposiciones dictados en aplicación de los reales decretos de declaración y prórroga del estado de alarma cuando los estimen lesivos de derechos fundamentales o libertades públicas (FJ 11).

En fin, concluye la Sentencia, en nuestro ordenamiento «todos los actos gubernamentales y parlamentarios de declaración, autorización y prórroga de cada uno de los tres estados de emergencia $e x$ art. 116 CE quedan sometidos, en razón de su condición de actos y disposiciones con fuerza o rango de ley, a un mismo régimen de control jurisdiccional ante este TC».

2. Doce de las Sentencias dictadas durante este cuatrimestre han versado sobre la figura del decreto-ley, tanto en el ámbito estatal como autonómico. La concurrencia o no del presupuesto habilitante ex art. 86.1 CE para la utilización de este tipo fuente ha sido abordada en las sentencias que seguidamente se reseñan, en las que se reitera la consolidada doctrina constitucional sobre dicho presupuesto ${ }^{20}$.

a) En la STC 18/2016 (Pleno), de 4 de febrero, se enjuicia la conformidad de diversos preceptos del Real Decreto-ley 20/2012, de 13 de julio, de medidas para garantizar la estabilidad presupuestaria y de fomento de la competitividad con los presupuestos y límites del art. 86.1 CE.

En relación con las modificaciones introducidas en el régimen de permisos y vacaciones de los funcionarios públicos, el TC desestima, con reproduc-

20 Además de las Sentencias de las que se da cuenta a continuación, también han versado sobre la figura normativa del decreto-ley y, en concreto, sobre la concurrencia o no de su presupuesto habilitante, las SSTC 19, 29, 30, 42 y 61/2016 (Pleno), que reiteran y reproducen la doctrina de la STC 270/2015 (Pleno), de 17 de diciembre (FJ 5), que resolvió el recurso de inconstitucionalidad interpuesto contra determinados preceptos del Real Decreto-ley 9/2013, de 12 de julio, que establecen un nuevo régimen retributivo para las instalaciones de producción de energía eléctrica a partir de fuentes de energía renovable, cogeneración y residuos y que habilitan al Gobierno para la aprobación por real decreto del régimen jurídico y económico de estas instalaciones con retribución primada (véase la reseña publicada en $R E D C$, núm. 106, 2016, p. 350). 
ción de la doctrina de la STC 156/2015 (Pleno), de 9 de julio (FJ 5) ${ }^{21}$, que la falta de eficacia inmediata de la reforma, cuya entrada en vigor se pospuso al día 1 de enero de 2013, suponga una desconexión entre las concretas medidas adoptadas y la situación de urgencia invocada — situación de recesión de la economía española—, ya que

su aplicación a mitad de año hubiera podido incidir de modo notable en los intereses de las administraciones públicas destinatarias del nuevo régimen, que necesariamente han de precisar de un cierto margen de tiempo entre la aprobación de la norma legal y su entrada en vigor para organizar sus estructuras y servicios y adaptarlos al nuevo sistema de permisos y vacaciones, teniendo en cuenta, también, los intereses de los funcionarios públicos dependientes de aquella» $[\mathrm{FJ} 5, a)]$.

Respecto de las medidas introducidas en la organización, contenido y gastos de las prestaciones para atender a las situaciones de dependencia, el TC entiende que el Gobierno ha justificado de manera suficiente la existencia de una situación de extraordinaria y urgente necesidad, referida a una «situación de recesión y crisis económica y financiera, real y conocida y a la exigencia de cumplimiento de unos compromisos internacionales de déficit igualmente notorio, que tienen por objeto atender a lo que cabe calificar como una "coyuntura económica problemática» [...], concretada, en lo que hace a la presente impugnación, en la necesidad urgente de asegurar la sostenibilidad presente y futura del sistema de atención a la dependencia, corrigiendo una situación que, a juicio del Gobierno, ha supuesto consecuencias perjudiciales para el mismo en un contexto de dificultades económicas». También aprecia que concurre la conexión de sentido entre la situación de urgencia definida y las medidas adoptadas, dado que «todas ellas buscan, de uno u otro modo, redefinir el sistema de atención a la dependencia en la forma que el Gobierno ha considerado necesaria para asegurar su sostenibilidad, pues se orientan, fundamentalmente, a generar ahorros inmediatos en el gasto público dedicado a la dependencia». Y, por último, el TC descarta que se trasgreda la prohibición constitucional de afectar al régimen de las comunidad autónomas, por prever la constitución del Consejo Territorial de Servicios Sociales y del Sistema para la Autonomía y Atención a la Dependencia, resultado de la refundición de órganos de cooperación hasta entonces existentes, ya que «una disposición del Gobierno, tendente a restructurar los instrumentos de cooperación necesarios en el ámbito de la promoción de la autonomía y atención a

21 Vid. la reseña publicada en $R E D C$, núm. 105, 2015, pp. 209-211. 
las personas en situación de dependencia, no persigue una delimitación directa y positiva de las competencias mediante el Decreto-ley, pues este límite material no impide cualquier regulación que indirectamente incida en las competencias autonómicas» [FJ 5,b)].

Por lo que se refiere a los preceptos que introducen una mayor liberalización de horarios y días de apertura de domingos y festivos de establecimientos comerciales, así como que modifican la normativa hasta entonces vigente reguladora de todo tipo de actividades de promoción de ventas, se reproduce en la Sentencia la doctrina de la STC 156/2015 (Pleno), de 9 de julio ${ }^{22}$ (FJ 6), para concluir que el Gobierno

ha explicitado la existencia de una situación de extraordinaria y urgente necesidad por referencia a la coyuntura económica y a la necesidad de propiciar el crecimiento de la productividad y la competencia», concurriendo también el requisito de la «conexión de sentido entre la situación de urgencia apreciada por el Gobierno y las medidas adoptadas paras hacerle frente [FJ $5, c)]$.

b) Por su parte, las SSTC 26/2016 (Pleno), de 18 de febrero, 67 y 68/2016 (Pleno), de 14 de abril, y 84/2016 (Pleno), de 28 de abril, resuelven los recursos de inconstitucionalidad promovidos por los gobiernos de distintas comunidades autónomas contra determinados preceptos del Real Decretoley 14/2012, de 20 de abril, de medidas urgentes de racionalización del gasto público en el ámbito educativo.

El TC entiende que el Gobierno ha justificado de manera suficiente, razonada y explícita la concurrencia de una situación de extraordinaria y urgente necesidad justificativa del uso de esta figura normativa, al tratar de cumplir los objetivos de déficit comprometidos por España como consecuencia de su pertenencia a la Unión Europea y a la zona euro en particular, adoptando una serie de medidas de racionalización del gasto educativo dirigidas al cumplimiento de dichos objetivos (SSTC 26/2016, FJ 3; 67 y 68/2016, FJ 3; 84/2016, FFJJ 3 y 4).

La relación de conexión de las medidas adoptadas con la situación de urgente necesidad que con ellas se pretende afrontar viene condicionada en este supuesto por dos circunstancias. De un lado, por el carácter competencialmente compartido de las materias educación y función pública afectadas por el Real Decreto-ley, «que hace que la regulación estatal precise de ordinario de un desarrollo, que no corresponde hacer al Estado, sino a las Comunidades Autónomas», de manera que

22 Vid. la reseña publicada en $R E D C$, núm. 105, 2015, pp. 209-210. 
aunque la efectividad real o material de una medida no sea estrictamente inmediata, al estar necesitada de desarrollo y aplicación, a efectos de valorar su urgencia o perentoriedad, es preciso atender a la justificación de la necesidad de la actuación expedita del Estado en el ejercicio de sus competencias, y no a la cadena de efectos sucesivos que sus decisiones deban tener para producir un impacto final en la realidad.

De otro lado, por el desarrollo del sistema educativo en cursos escolares que se programan y se suceden anualmente y sin coincidir con el año natural, de forma que

cuando una medida de reforma educativa afecta a la organización y prestación del servicio docente, la situación de extraordinaria y urgente a atender consiste con frecuencia en la necesidad de llegar a tiempo al comienzo del siguiente curso (y si es posible al período previo de su programación) para que esa reforma pueda ser efectiva sin provocar dificultades insalvables para los responsables de la prestación del servicio educativo involucrados en su aplicación (STC 68/2016, FJ 3).

A partir de las peculiaridades expuestas, se analizan en las sentencias cada una de las medidas cuestionadas. Así, respecto del art. 2, que permite a las administraciones educativas ampliar el número máximo de alumnos por aula en los centros docentes públicos y concertados mientras en las leyes de presupuestos generales del Estado se disponga la congelación de incorporación de personal de nuevo ingreso o se fije una tasa anual de reposición efectiva por debajo del $50 \%$, el TC aprecia que concurre la necesaria relación de conexión entre la medida adoptada y la situación de extraordinaria y urgente necesidad. Se argumenta que la inclusión de la medida en una ley hubiera sido posible, pero su tramitación parlamentaria hubiera culminado sin duda de manera demasiado próxima al inicio del curso 2012-2013 en que se quiere aplicar, con las consiguientes distorsiones organizativas. Por otra parte, la medida, en lo que afecta a la configuración de las plantillas docentes, guarda relación con los objetivos de racionalización del gasto público en un contexto de dificultades económicas, sin que tenga carácter definitivo, pues está vinculada a las circunstancias extraordinarias de congelación de la oferta pública de empleo y de control de la tasa de reposición de efectivos en las administraciones públicas [STC 26/2016, FJ 5, a)].

En relación con el número de horas lectivas por profesor establecido en el art. 3 y el régimen de sustituciones de profesores del art. 4, el Tribunal entiende que se trata de medidas que exigen por la propia naturaleza de la materia «su adopción inmediata, sin confiarlas al ritmo de la tramitación propio 
del legislador ordinario, con el fin de que pudieran tener impacto en los siguientes presupuestos públicos educativos a aprobar, y por tanto en el logro de la consolidación fiscal que se consideraba clave para salir de la crisis económica». Por lo demás, el establecimiento de horas lectivas «tiene como finalidad la contención de los gastos de personal docente, mediante la fijación de un mínimo de dedicación lectiva que pretende maximizar el aprovechamiento de los recursos de personal docente de los centros». Y, por su parte, la regulación de la sustitución de profesores, al prever la no cobertura de las bajas y ausencias breves de profesores mediante la contratación de personal interino, es una medida de contención del gasto para contribuir al objetivo conjunto de la reducción del déficit público (SSTC 67 y 68, FJ 3; 84/2016, FJ 3).

$\mathrm{El}$ art. 5, que permite posponer hasta dos cursos académicos la implantación del nuevo régimen de ordenación de las enseñanzas de formación profesional a excepción del régimen especial de los centros militares, previendo, en todo caso, que las administraciones educativas pueden renunciar a este aplazamiento y ordenar la implantación de todo o parte del nuevo régimen de estas enseñanzas, presenta, a juicio del TC, la necesaria conexión de sentido con la situación de extraordinaria y urgente necesidad, ya que se trata de una norma que "produce el efecto inmediato de permitir a las comunidades autónomas tomar a su vez las decisiones que les corresponden sobre la impartición de este tipo de enseñanzas». Y, por otra parte, dado que la implantación de esas nuevas enseñanzas conlleva necesariamente un importante desembolso de gasto público, su aplazamiento, a la vista de las circunstancias económicas, puede resultar oportuno o conveniente [STC 26/2016, FJ 5, b)].

Por el contrario, el TC estima que los apartados 1 y 2 del art. 6 no presentan la necesaria relación de conexión con la situación de urgencia que justifica el recurso a la figura del Decreto-ley, por lo que declara su inconstitucionalidad y nulidad. La novedad introducida por ambos apartados está constituida por la remisión a un reglamento, previa consulta separada de órganos de participación de las universidades y de las comunidades autónomas, a fin de que el Gobierno apruebe los requisitos básicos para la creación, mantenimiento y supresión de los centros y estructuras de las universidades públicas. Se argumenta en la Sentencia que esta remisión a una norma posterior, que a su vez exige una consulta previa de los órganos señalados, «impide considerar que se ha cumplido el requisito de la conexión de sentido entre la medida y la situación de urgencia que se pretende atender, en la medida en que la inmediatez de lo que prescribe el Decreto-ley no se puede dar por descontada, pues depende de una actuación ulterior del Gobierno». El ahorro en el gasto se derivaría en todo caso no de la habilitación en sí, sino de las concretas previsiones reglamentarias que, además, el Gobierno podría modificar sin el recurso a la legislación de urgencia [STC 26/2016, FJ 5, c)]. 
Tampoco queda justificada la conexión de sentido del art. 6.3, que reconoce a las universidades la posibilidad de crear alianzas estratégicas no solo para programas o proyectos de excelencia internacional, sino también para desarrollar conjuntamente enseñanzas conducentes a la obtención de títulos universitarios de carácter oficial. El precepto —entiende el TC — no incluye ninguna medida de carácter inmediato, pues para ser efectivo depende de la voluntad cooperadora de las universidades entre sí o de estas con otros agentes, sin que se aporte razón alguna de la relación que tiene esa medida con el ahorro del gasto mediante la racionalización de las titulaciones de grado [STC 26/2016, FJ 5, c)].

El TC considera cumplida la conexión de sentido entre la situación de urgencia definida y la medida contemplada en el art. 6.4, que modula la carga docente del profesorado universitario de categoría funcionarial en atención a los méritos individuales de investigación que acrediten, de manera que a mayor dedicación investigadora corresponde una menor dedicación docente y viceversa. Se trata de una medida que pretende contribuir a la reducción del gasto público educativo de las comunidades autónomas, en el que uno de los principales componentes son los costes de personal de las universidades públicas, pues las nuevas reglas de dedicación determinaran un incremento de la capacidad docente total de las plantillas de las universidades y, por consiguiente, reducirá las necesidades de profesorado de estas. Además la medida tiene un efecto jurídico inmediato, pese a que su efectividad se vincula a las necesidades de la programación universitaria, ya que la puesta en práctica de las nuevas reglas solo podría alcanzarse al inicio del curso académico siguiente, pero para ello era necesario que la reforma estuviese aprobada al tiempo de prepararse la programación docente de las universidades [SSTC 26/2016, FJ 5, c); 84/2016, FJ 3].

Y, por último, se aprecia también la necesaria conexión de sentido en relación con el art. 7, que conlleva que las comunidades autónomas hagan frente al incremento correspondiente del coste público de las becas si elevan los precios públicos de matrícula por encima del límite inferior de la horquilla fijada en la legislación estatal, dado que constituye una medida que asociada a un nuevo sistema de precios universitarios produce mayores ingresos públicos bajo el control de las comunidades autónomas, de modo que puede tener impacto en los siguientes presupuestos públicos educativos a aprobar y, por tanto, en el logro de la consolidación fiscal para salir de la crisis económica (STC 84/2016, FJ 4).

c) El Tribunal aprecia en la STC 38/2016 (Pleno), de 3 de marzo, que el Gobierno balear ha cumplido la exigencia de exponer explícita y razonadamente la situación de extraordinaria y urgente necesidad que le habilita para dictar el Decreto-ley 5/2013, de 6 de septiembre, por el que se adoptan deter- 
minadas medidas urgentes en relación con la implantación, para el curso 2013-2014, del sistema de tratamiento integrado de las lenguas en los centros docentes no universitarios de las Illes Balears. Se razona en la Sentencia que, después de haber suspendido por resolución judicial únicamente el calendario inicialmente previsto de implantación del referido sistema unos días antes de comenzar el curso escolar, y de haberse mantenido vigente el resto de la regulación, era necesaria una acción normativa inmediata que permitiese la aplicación de los proyectos de tratamiento integral de las lenguas aprobados por cada centro docente para lo que ya se había llevado a cabo la correspondiente planificación de recursos económicos, humanos y pedagógicos (FFJ 3 y 4). Sin embargo, el TC considera que algunas de las medidas contenidas en el Decreto-ley impugnado (arts. 4, 5 y disposición adicional única) no guardan la necesaria conexión de sentido con la situación que se trata se subvenir, pues resultan ajenas o, cuando menos, muy alejadas del sentido de la medida de aprobación del calendario escolar que el Decreto-ley implementa por razones de urgencia para la aplicación al inicio del curso de los proyectos de tratamiento integral de lenguas en los respectivos centros educativos, sin que nada permita suponer que aquellas medidas no hubieran podido ser adecuadamente encauzadas mediante el ejercicio ordinario de las potestades normativas del Consejo de Gobierno o, en su caso, del Parlamento de la comunidad autónoma (FJ 5).

Por otra parte, el TC descarta que el Decreto-ley recurrido haya trasgredido la prohibición recogida en los arts. 86.1 CE y 49.1 EAIB de afectar a los derechos constitucionales y estatutarios, en concreto, al derecho a la educación, dado que la aprobación de un calendario que se limita a concretar en qué cursos del segundo ciclo de educación infantil, de educación primaria y de educación secundaria obligatoria han de aplicarse los proyectos de tratamiento integral de lenguas, cuya constitucionalidad no se cuestiona; se sitúa en el ámbito meramente procedimental, pero no interfiere en el contenido material del proyecto educativo, de modo que no afecta al régimen general del derecho a la educación, ni al contenido o elementos esenciales de dicho derecho (FJ 6).

d) Y, en fin, en la STC 70/2016 (Pleno), de 14 de abril, el Tribunal concluye que el Gobierno no ha justificado la concurrencia del presupuesto de la extraordinaria y urgente necesidad para haber recurrido a la legislación de urgencia al objeto de modificar el art. 7.1.a) de la Ley 38/2003, de 17 de noviembre, general de subvenciones.

El precepto recurrido dispone que la responsabilidad de las administraciones públicas que gestionen Fondos Europeos que tengan su origen en correcciones financieras acordadas mediante sentencias, actos o decisiones dictados por las instituciones europeas se determinará y repercutirá conforme al régimen establecido en la Ley Orgánica 2/2012, de 27 de abril, de estabilidad 
presupuestaria y sostenibilidad financiera y su normativa de desarrollo. Para el TC el citado precepto se limita a introducir una mejora técnica, pero no innova la regulación del régimen de traslado de responsabilidad en lo que se refiere a los posibles incumplimientos del derecho de la Unión Europea, pues se remite al régimen jurídico de responsabilidad por incumplimiento del derecho comunitario establecido en la Ley de estabilidad presupuestaria y sostenibilidad financiera, que permitía ya el traslado de responsabilidades derivadas de posibles condenas. Así pues, en el momento de dictarse el Decreto-ley ya existía en nuestro Ordenamiento un sistema que permitía al Estado repercutir ad intra la responsabilidad que en cada caso procediera, pudiendo iniciarse, en consecuencia, los procedimientos de repercusión de responsabilidades que fueran necesarios para que las condenas al Reino de España por incumplimiento de obligaciones fueran trasladadas a la Administración competente (FFJJ 6 y 7 ).

3. El ATC 84/2016 (Pleno), de 26 de abril, inadmite por notoriamente infundada la cuestión de inconstitucionalidad promovida por el Juzgado de lo Contencioso-Administrativo núm. 1 de Orense en relación con el párrafo segundo de la disposición adicional vigésimo primera de la Ley de la comunidad autónoma de Galicia 11/2013, de 26 de diciembre, de presupuestos generales para 2014, que incrementa el canon que los entes locales deben abonar a una sociedad pública autonómica por la gestión de residuos urbanos municipales.

Con reproducción de la doctrina de la STC 203/2013 (Pleno), de 5 de septiembre $(\mathrm{FJ} 4)^{23}$, el TC considera que la disposición cuestionada ha de ser calificada ciertamente como una ley de contenido singular, pero concluye que respeta las exigencias que a este tipo de fuente impone la jurisprudencia constitucional. Así, estima que se trata de una medida que responde a una situación excepcional, pues se ha adoptado con el fin de "garantizar la sostenibilidad financiera del sistema»; que no puede ser tomada por la Administración, pues esta carece de potestades para alterar el régimen jurídico de los contratos suscritos por terceros y modificar el precio fijado en los mismos, de modo que la medida solo puede ser adoptada por el legislador; que, además, no impide o condiciona el ejercicio de derechos fundamentales; y, en fin, que supera el canon de razonabilidad, proporcionalidad y adecuación, ya que la disposición cuestionada tiene una justificación objetiva — garantizar la sostenibilidad financiera del sistema-, y es adecuada y proporcionada para conseguir el fin perseguido (FJ 4$)^{24}$.

23 Vid. la reseña publicada en REDC, núm. 100, pp. 274-276.

24 Juan Carlos Duque Villanueva. 


\section{ESTRUCTURA TERRITORIAL DEL ESTADO}

1. La Sentencia protagonista en el período es, sin duda, la STC 41/2016 (Pleno), de 3 marzo de 2016, que resuelve el recurso de inconstitucionalidad interpuesto por la Asamblea de Extremadura contra diversos preceptos de la Ley 27/2013, de 27 de diciembre, de racionalización y sostenibilidad de la Administración local (LRSAL). Se trata del primero de los pronunciamientos del Tribunal sobre esta importante reforma de la administración local que introduce modificaciones sustanciales en la Ley reguladora de las Bases de Régimen Local (LRBRL) y en el texto refundido de la Ley Reguladora de las Haciendas Locales (TRLHL) —el BOE de 31 de mayo de 2014 publicó las providencias de admisión de otros ocho recursos contra la Ley y en septiembre del mismo año el TC admitió también a trámite un conflicto en defensa de la autonomía local contra preceptos de la misma norma presentado por cerca de tres mil municipios- y ha sido considerado por los críticos de la reforma un golpe severo al esquema de la LRSAL. La Sentencia, parcialmente estimatoria, declara la inconstitucionalidad y nulidad de un apartado del art. 1 (que da redacción al art. 57 bis de la LRBRL), de tres disposiciones transitorias al completo - y, por conexión, de una disposición adicional — e incisos de otras dos, y fija la interpretación conforme de otra de las disposiciones adicionales. La larga «nota informativa» difundida desde la página web del TC, al tiempo que anunciaba la adopción de la decisión y proporcionaba un resumen de esta, se encargaba de resaltar que la Sentencia «aval[a] la constitucionalidad de la mayor parte de las previsiones impugnadas» y que «solo algunos de los preceptos y disposiciones recurridos rebasan los límites marcados por [la] doctrina y son declarados inconstitucionales y nulos». Innecesario advertir que este tipo de valoración, vamos a decir, "cuantitativa», no dice mucho del verdadero alcance de un pronunciamiento constitucional.

Apelando a doctrina constitucional bien establecida, la STC 41/2016 declara inconstitucionales y nulas las disposiciones transitorias primera, segunda y tercera de la LRSAL, muy polémicas en el debate de la reforma, que imponían la centralización en las comunidades autónomas de competencias tradicionalmente asignadas a los entes locales, en relación con servicios sociales, atención primaria a la salud o mataderos, y desactiva, por vía de interpretación conforme, la previsión de la disposición adicional decimoquinta que pretendía lo mismo respecto de competencias educativas. En buena lógica, lo que concluye el TC es que estas competencias serán autonómicas o locales, dependiendo de lo que decidan las comunidades autónomas, que son al fin y al cabo las que tienen competencia en estas materias: 
el Estado solo podrá atribuir competencias locales específicas, o prohibir que éstas se desarrollen en el nivel local, cuando tenga la competencia en la materia o sector de que se trate. En materias de competencia autonómica, solo las comunidades autónomas pueden atribuir competencias locales o prohibir que el nivel local las desarrolle (FJ 13).

Advierte asimismo el TC que si el Estado en materia de régimen local (art. 149.1.18 CE) tiene la responsabilidad de perseguir los objetivos constitucionales y cumplir con los mandatos de eficiencia, eficacia y estabilidad presupuestaria (arts. 31.2, 103.1 y $135 \mathrm{CE}$ ), no es menos cierto que esos mismos objetivos y mandatos se dirigen también a las comunidades autónomas, que deben darles cumplimiento en el marco de sus atribuciones estatutarias. Por tanto, «el art. $135 \mathrm{CE}$ no puede traducirse en una alteración radical de la doctrina constitucional que permita al Estado eliminar las competencias que los Estatutos de Autonomía, dentro del marco establecido por la Constitución, asignan a las comunidades autónomas para organizar sus servicios» (FJ 13). La «racionalización» de la administración local, en definitiva, no puede ignorar el mapa — racional o no- de distribución competencial.

Resulta interesante que el TC, aun cuando desarrolla un argumento en abstracto, tenga bien presente y haga referencia al statu quo ante que la Ley ha buscado alterar. Sin sugerir nada en cuanto a las supuestas ventajas del nuevo modelo de prestación de servicios, no pasa por alto las dificultades de la transición que la LRSAL impone (de las que, de hecho, da testimonio el aluvión de normas autonómicas de diverso rango y alcance orientadas a ordenar este tránsito, evitar disfuncionalidades y garantizar los servicios mientras se produce el definitivo reacomodo de los mismos entre los distintos niveles de gobierno). Precisamente, al analizar la disposición adicional decimoquinta, sobre las competencias en materia educativa hasta ahora asumidas por los municipios, el propio TC llama la atención sobre el dilema sin solución provocado por el legislador estatal, que reclama a un tiempo la descentralización y centralización de los servicios, una "antinomia» que va a solucionar por vía de interpretación, en consonancia con lo ya resuelto respecto de las competencias en asistencia social y salud: queda a la decisión de la comunidad autónoma la opción de centralizar, asegurando en todo caso competencias propias de los municipios en este ámbito [FJ 13,e)].

Frente a la opinión de los críticos de la LRSAL, es aventurado calificar el enfoque de la Sentencia de "municipalista» o "autonomista». Aunque estas declaraciones de inconstitucionalidad parecen dar al traste con la pretensión estatal de diseñar un patrón básico y homogéneo para todo el territorio del sistema de prestación de servicios, en conjunto, la Sentencia da por bueno - o, por lo menos, no considera inconstitucional — el grueso de la reforma 
(redefinición de las competencias de los municipios, apuesta por la limitación de las entidades locales menores, limitación de competencias de las mancomunidades, nueva regulación de las modalidades de gestión directa de servicios públicos, nuevo régimen jurídico de los consorcios).

Las declaraciones de inconstitucionalidad que afectan a otros preceptos no se refieren a aspectos sustantivos, y en el caso de la declaración de inconstitucionalidad del art. 57 bis de la LRBRL (por «inmiscuirse» en la relación financiera de las comunidades autónomas con el Estado, reservada a la ley orgánica por el art. 157.3 CE), la protección del sistema de relaciones Estadocomunidad autónoma, tiene el efecto de inutilizar un instrumento previsto en la Ley para dar solución al problema recurrente de los impagos de las comunidades autónomas a entes locales. El precepto anulado atribuía al Estado la facultad de practicar retenciones en las transferencias que corresponden a las comunidades autónomas por aplicación del sistema de financiación, como una garantía del pago de sus compromisos económicos derivados de la delegación de competencias a las entidades locales. La observación realizada de pasada en cuanto a la constitucionalidad de la fórmula en sí resulta bastante desconcertante:

El art. 57 bis LBRL permite que el Estado ejerza una competencia autonómica, por más que esta sustitución esté evidentemente acotada, por ceñirse al pago de determinadas obligaciones contraídas por la Comunidad con sus entes locales. Esta injerencia en la autonomía politica de las comunidades autónomas será o no legitima — no es el momento para valorarlo-, pero constituye en todo caso una injerencia que, en cuanto tal, exige la regulación con rango de ley orgánica (FJ 16).

2. El TC descarta en la STC 41/2016 que el título estatal sobre ordenación general de la economía del art. 149.1.13 CE tenga parte en el encuadramiento competencial de la controversia y aprovecha para realizar los consabidos caveats a propósito de la conveniencia de proceder a un entendimiento restringido de su alcance: se hace preciso «evitar una lectura excesivamente amplia» que pueda "constreñir de contenido o incluso vaciar las competencias sectoriales legítimas de las comunidades autónomas», señala en el FJ 3. No obstante, pocas dudas hay de la polivalencia y creciente ubicuidad de este potente título de intervención estatal, como se pone de manifiesto en muchas de las decisiones del período en las que directa o indirectamente está en cuestión el alcance de la competencia básica estatal en ámbitos muy diversos.

Así, por ejemplo, en la STC 88/2016 (Pleno), de 28 de abril, que respalda la competencia del Estado para fijar mediante norma básica límites que vedan cualquier incremento de gasto global en materia de personal por parte 
de las comunidades autónomas; o en las SSTC 18/2016 (Pleno), de 4 de febrero $^{25}$; 37/2016 (Pleno), de 3 de marzo; 55/2016 (Pleno), de 17 de marzo, y 59/2016 (Pleno), de 17 de marzo, a propósito del alcance de la regulación básica que incide en la competencia autonómica sobre comercio interior; o en la serie de sentencias que resuelven recursos interpuestos contra la ley estatal reguladora del sector eléctrico [STC 32/2016 (Pleno), de 18 de febrero; 60/2016 (Pleno), de 17 de marzo; 72/2016 (Pleno), de 14 de abril); o, en fin, en la Sentencia 62/2016 (Pleno), de 17 de marzo, en la que el TC declaró inconstitucionales y nulas, por contradecir la legislación básica, las previsiones del Código de Consumo de Cataluña que establecían la prohibición de corte de suministro de luz y gas por impago de facturas a los consumidores que la norma autonómica caracterizaba como vulnerables. Los votos particulares que acompañan esta decisión ( $\mathrm{y}$ a las anteriores, en relación con la Ley del sector eléctrico) cuestionan de partida la lectura que la mayoría del TC hace del título que ampara la competencia básica.

3. La Sentencia 56/2016 (Pleno), de 17 de marzo, resuelve el recurso de inconstitucionalidad interpuesto frente a la Ley de Cortes de Aragón 3/2013 de uso, protección y promoción de las lenguas y modalidades lingüísticas propias de Aragón. Lo más pintoresco de la Ley, que le valió una fugaz fama, fue la omisión de cualquier referencia al catalán y aragonés como lenguas propias de Aragón, para referirse en su lugar y respectivamente a «la lengua aragonesa propia del área oriental» (LAPAO) y a «la lengua aragonesa propia de las áreas pirenaica y prepirenaica» (LAPAPIP). Esta opción, considerada por los recurrentes una forma de discriminar a las minorías de hablantes de las lenguas tradicionales, al despojar a estas de un elemental signo de identidad como es el nombre, fue revisada por el propio legislador aragonés, que en la Ley 2/2016 recuperó la denominación habitual de aragonés y catalán, de modo que para cuando se dicta la Sentencia, este concreto motivo de impugnación ha perdido objeto. La Sentencia es desestimatoria del recurso pero da ocasión al TC de detenerse a analizar el estatus de aquellas lenguas territoriales que, sin tener la consideración de oficiales, están reconocidas en los Estatutos de Autonomía y a las que, en consecuencia, les son de aplicación las previsiones de la Carta Europea de lenguas regionales y minoritarias en los términos convenidos por el Estado en el momento de su ratificación ${ }^{26}$.

25 Comentada supra, pp. 297-299.

26 Marian Ahumada Ruiz. 


\section{ORGANIZACIÓN TERRITORIAL DEL ESTADO}

1. En este apartado de la crónica ha de resaltarse durante el primer cuatrimestre de este año la STC 10/2016 (Sala Primera), de 1 de febrero ${ }^{27}$, en cuanto cabe apreciar en ella una inflexión, al menos en su enunciado, en la actual doctrina constitucional sobre el alcance de la función de las mesas de las asambleas legislativas de calificación y admisión a trámite de las iniciativas parlamentarias. La Sentencia resuelve el recurso de amparo promovido por el Grupo Parlamentario Socialista en la Asamblea de Extremadura contra los acuerdos de la mesa de la cámara que inadmitieron a trámite una proposición de ley en defensa de la sanidad pública.

En torno a la función de las mesas de las cámaras de calificación y admisión a trámite de las iniciativas parlamentarias, se ha elaborado una doctrina constitucional no exenta de giros y oscilaciones, pero que en la actualidad puede afirmarse que cuenta con unos criterios jurisprudenciales consolidados. La principal cuestión controvertida en relación con dicha función ha estribado en la posibilidad y, en su caso, con qué alcance, de que las mesas, al calificar y decidir sobre la admisión a trámite de las iniciativas parlamentarias, puedan llevar a cabo un control de legalidad y también de constitucionalidad de estas, más allá del estricto examen de los requisitos legales que el ordenamiento establece para cada tipo de iniciativa ${ }^{28}$.

La STC 124/1995, de 18 de julio, inicia una línea jurisprudencial sobre el alcance de la función de las Mesas de calificación y admisión a trámite de las iniciativas parlamentarias, sean de naturaleza legislativa o de control de la acción de gobierno, de la que son exponentes numerosos pronunciamientos del Tribunal, como revelan las más recientes Sentencias en la materia (entre otras, SSTC 191/2013, de 18 de noviembre, FJ 3; 200/2014, de 15 de diciembre, FJ 4; 202/2014, de 15 de diciembre, FJ 3; 158/2014, de 6 de octubre, FJ 4; 1/2015, de 19 de enero, FFJ 3 y 6; 23/2015, de 16 de febrero, FJ 3), pasando por el Auto del Pleno 85/2006, de 15 de marzo $^{29}$, que excluyen

27 Comentada infra, pp. 320-321.

28 Para una exposición sobre la evolución de la jurisprudencia constitucional en relación con el alcance de la función de las mesas de las cámaras de calificación y admisión a trámite de las iniciativas parlamentarias, vid. Duque Villanueva, J. C., «El Parlamento en la jurisprudencia constitucional. Una visión de conjunto", en Jurisprudencia parlamentaria, Vitoria-Gasteiz, 2009, pp. 74-88.

29 El ATC 85/2006, de 15 de marzo, inadmitió a trámite, por carecer manifiestamente la demanda de contenido constitucional, el recurso de amparo promovido por dipu- 
posibilidad de que en el ejercicio de aquella función las mesas de las cámaras puedan llevar a cabo un control de legalidad o constitucionalidad del contenido de la iniciativa parlamentaria, como se sostuvo inicialmente, por el contrario, en la STC 205/1990, de 13 de diciembre ${ }^{30}$.

De acuerdo con esta consolidada hasta ahora doctrina constitucional ningún reparo puede merecer desde una perspectiva constitucional la atribución a las mesas de las cámaras de la función de controlar la regularidad legal de las iniciativas parlamentarias, siempre que su examen, realizado en contraste con la regulación parlamentaria, no encubra un juicio sobre la oportunidad de la iniciativa en los casos que ese juicio este atribuido a la cámara en Pleno o a alguno de los órganos intraparlamentarios ante los que deba tramitarse la iniciativa. Ello no significa que el examen por las mesas de la cámara de las iniciativas parlamentarias deba circunscribirse a una verificación de sus requisitos formales, sino que puede extenderse a aspectos materiales de la iniciativa cuando esta venga materialmente limitada por la Constitución, el bloque de la constitucionalidad o el Reglamento parlamentario, de modo que, si la legalidad aplicable no impone limite material alguno a la iniciativa parlamentaria en cuestión la verificación de su admisibilidad por las mesas, ha de ser siempre formal (por todas, SSTC 82/2012, de 7 de mayo, FJ 2; 191/2013,

tados del Grupo Parlamentario Popular contra la decisión de la Mesa del Congreso de los Diputados por la que se calificó la propuesta de reforma del Estatuto de Autonomía de Cataluña presentada por el Parlamento de esta comunidad autónoma como una propuesta de reforma de Estatuto de Autonomía, se admitió a trámite, se dio traslado de esta al Gobierno, se publicó en el Boletín Oficial de las Cortes Generales y, en fin, se decidió seguir para su tramitación el procedimiento establecido en la Resolución de la Presidencia del Congreso de los Diputados de 16 de marzo de 1993, sobre el procedimiento a seguir para la tramitación de la reforma de los Estatutos de Autonomía. Vid. la reseña publicada en REDC, núm.77, 2006, pp. 232-234.

30 La STC 205/1990, de 13 de diciembre, inadmitió a trámite el recurso de amparo promovido por el portavoz del Grupo Parlamentario de Convergencia i Unió contra la decisión de la Mesa del Senado de no admitir una moción sobre el uso de las lenguas cooficiales en la cámara alta por entenderla contraria a las previsiones de la Constitución y de los Estatutos de Autonomía. El TC extendió en dicha Sentencia la función de calificación y admisión a trámite de las iniciativas parlamentarias a una verificación liminar de la conformidad a derecho de la pretensión deducida, que permite que la Mesa pueda acordar la inadmisión de la iniciativa en cuestión cuando el contenido de la moción sea manifiestamente contrario a derecho o inconstitucional (FJ 6). Esta doctrina se reproduce en otros pronunciamientos del TC (SSTC 225/1992, de 14 de diciembre; 76/1994, de 14 de marzo; 95/1994, de 21 de marzo; ATC 155/1993, de 24 de mayo). 
FJ 3; 200/2014, FJ 4; 202/2014, FJ 3; 1/2015, FFJJ 3 y 6; 23/2015, FJ 6). En el bien entendido, como se señala en el ATC 85/2006, que este control material sobre la legalidad de la iniciativa parlamentaria «la hemos circunscrito a aquellos casos en los que la calificación de la iniciativa - y su correspondiente tramitación - se define en atención a criterios de orden material, por lo que dicha calificación solo puede llevarse a cabo analizando el contenido material de la iniciativa por ser este determinante, como así sucede, por ejemplo, con las preguntas, interpelaciones y mociones que como instrumentos parlamentarios de control se diferencian entre sí por su contenido; y a aquellos supuestos en los que la iniciativa parlamentaria se encuentra materialmente limitada por estarle constitucional o legalmente vedadas determinadas materias» (FJ 3). Lo que en todo caso queda descartado, como se indica en el citado Auto, es, fuera de los supuestos señalados, un control, si quiera liminar, sobre la legalidad o constitucionalidad del contenido de la iniciativa parlamentaria (FJ 5). En otras palabras, las mesas no pueden llevar a cabo un control de legalidad o constitucionalidad del contenido de la iniciativa parlamentaria que trascienda el de los límites materiales que, en su caso, para la iniciativa parlamentaria establezca el ordenamiento jurídico, debiendo circunscribirse, por lo tanto, su labor fiscalizadora a la legalidad que configura y define la iniciativa parlamentaria, si ésta resulta materialmente limitada por aquella.

Pues bien, la Sentencia que se reseña, si bien señala, con reproducción de la doctrina de la STC 124/1995, que «las Mesas han de abstenerse de realizar un pretendido juicio de constitucionalidad acerca de los contenidos de las propuestas de ley, admitiendo a trámite cuando se cumplan todas las formalidades reglamentariamente establecidas", afirma, seguidamente, sin solución de continuidad, con cita de las SSTC 95/1994 y 205/1990, que "'excepcionalmente" cabe que sea rechazada una propuesta de ley "cuando sea "contraria a la Constitución o ajena a las competencias atribuidas al ordenamiento en cuyo seno pretenda integrarse", exigiéndose para ello [...] que "la contradicción a Derecho o la inconstitucionalidad de la proposición sean palmarias y evidentes"» (FJ 4).

$\mathrm{Al}$ margen de la solución que se da al concreto caso planteado, lo relevante de la Sentencia es la inflexión que en ella cabe apreciar, al menos en su enunciado, respecto a la actual doctrina constitucional elaborada desde la STC 124/1995 sobre el alcance de la función de las mesas de calificación y admisión a trámite de las iniciativas parlamentarias, al venir a admitir la posibilidad por parte de las mesas de las cámaras de un control de legalidad y constitucionalidad sobre el contenido material de la iniciativa, más allá del estricto enjuiciamiento de los requisitos legales establecidos por el ordenamiento. Y no deja de resultar llamativo que se citen e invoquen conjuntamente y sin solución de continuidad las SSTC 124/1995 y 205/1990, cuando 
aquella ha supuesto un cambio radical, que llega hasta los últimos pronunciamientos del Tribunal en la materia, respecto a la doctrina mantenida inicialmente en esta última. El tiempo permitirá constatar si se trata de una inflexión jurisprudencial inadvertida, sin mayor trascendencia, o, por el contrario, supone un verdadero cambio de doctrina, respecto a la mantenida por el Pleno del Tribunal en el ATC 85/2006, además de en las sentencias antes citadas, que entronca con una vuelta a la doctrina de la STC 205/1990, con base en la cual las mesas de las cámaras pueden controlar la legalidad y constitucionalidad de las iniciativas parlamentarias y, por consiguiente, inadmitir aquellas que por su contenido resulten manifiesta o palmariamente ilegales o inconstitucionales ${ }^{31}$.

\section{DERECHOS FUNDAMENTALES}

1. Durante este cuatrimestre el TC ha consolidado la costumbre de explicitar en las sentencias la especial transcendencia constitucional de las demandas admitidas a trámite. Esta nueva situación crea situaciones comprometidas, ya que el TC, en ocasiones, se ve en el aprieto de forzar, en exceso, la explicación sobre tal circunstancia; valga como muestra la STC 49/2016 (Sala Segunda), de 14 de marzo, FJ 2, que, tras afirmar que va a proceder a aclarar o modificar la doctrina constitucional sobre la incongruencia omisiva, se remite a lo dicho en la STC 39/2015 (Sala Segunda), de 2 de marzo, en un caso similar. O la STC 16/2016 (Sala Segunda), de 1 de febrero, en la que se afirma que el recurso plantea un problema o afecta a una faceta de un derecho fundamental sobre el que no hay doctrina del TC (FJ 2), para seguidamente considerar que «el análisis constitucional en este proceso se ciñe a la vulneración del derecho fundamental a la tutela judicial efectiva sin indefensión (art. 24.1 $\mathrm{CE}$ ) en la vertiente de derecho a una resolución judicial motivada y fundada en derecho, que el recurso de amparo sustenta sobre una alegación general de falta de motivación y motivación defectuosa del Auto recurrido» (FJ 4). A continuación se comentan las sentencias más interesantes del cuatrimestre.

2. Sobre el derecho a la libertad (art. $17 \mathrm{CE}$ ) se han dictado tres sentencias que merecen un comentario especial, ya que se refieren a internamientos no voluntarios de personas con algún tipo de trastorno mental. En la primera de ellas, STC 13/2016 (Sala Primera), de 1 de febrero, la Sala Primera analizó el recurso plantado contra la resolución judicial que ratificó la medida

31 Juan Carlos Duque Villanueva. 
de internamiento urgente por trastorno psíquico de la recurrente; se denunciaba la lesión de los derechos fundamentales a la libertad personal (art. 17.1 $\mathrm{CE}$ ) y a la tutela judicial efectiva (art. 24.1 CE), por el incumplimiento de dos de los presupuestos para el internamiento urgente por trastorno psíquico: en primer lugar, que el Samur social se dirigió al Decanato de los Juzgados de Madrid tres días después del internamiento en la residencia geriátrica, rebasándose el límite legal e improrrogable de veinticuatro horas para realizar la comunicación al órgano judicial; y en segundo término, que la ratificación del internamiento se solicitó sin aportar un informe médico que motivara la procedencia de la medida. Así planteada la doble queja, estima el TC que la alegada vulneración del derecho a la tutela judicial efectiva por incumplimiento de los presupuestos y garantías del procedimiento del art. $763 \mathrm{LEC}^{32}$ ha de reconducirse al ámbito de la lesión del derecho a la libertad personal. Recalca que en los casos en que, por razones de urgencia, deba practicarse el internamiento involuntario con carácter previo a obtenerse la necesaria autorización judicial, la norma impone el deber de comunicar la adopción de la medida «al responsable del centro en que se hubiere producido el internamiento" y con el límite temporal de las veinticuatro horas. La «obligación del centro de comunicar al juez competente el internamiento y los motivos que lo justificaron» constituye una exigencia básica derivada del respeto al derecho fundamental a la libertad personal, y el plazo de veinticuatro horas para efectuar la comunicación es un plazo máximo que no tiene que agotarse necesariamente en el supuesto concreto ni cabe agotarlo discrecionalmente. Por tanto, la comunicación al órgano judicial debe ser efectuada por el director del centro en cuanto disponga del diagnóstico que justifique el internamiento, sin más demora; el plazo comenzará en el instante en que se producía materialmente el ingreso del afectado en el interior del recinto y contra su voluntad. Considera el TC que nada obsta a que una residencia geriátrica pueda ser el «centro» al que se refiere el art. 763.1 LEC, siempre que se halle en condiciones de cumplir con las condiciones imprescindibles para el tratamiento psiquiátrico. Por

32 Según dicho artículo: «1. El internamiento, por razón de trastorno psíquico, de una persona que no esté en condiciones de decidirlo por sí, aunque esté sometida a la patria potestad o a tutela, requerirá autorización judicial, que será recabada del tribunal del lugar donde resida la persona afectada por el internamiento. La autorización será previa a dicho internamiento, salvo que razones de urgencia hicieren necesaria la inmediata adopción de la medida. En este caso, el responsable del centro en que se hubiere producido el internamiento deberá dar cuenta de este al tribunal competente lo antes posible y, en todo caso, dentro del plazo de veinticuatro horas, a los efectos de que se proceda a la preceptiva ratificación de dicha medida [...]». 
otra parte, considera que el art. 763.1 LEC no contempla que la comunicación al órgano judicial la efectúen quienes intervienen en un momento anterior al inicio del internamiento, como sucede con el traslado del afectado al centro, tarea esta que puede corresponder en la casuística diaria a diversidad de personas, según las circunstancias. En el caso analizado, señala el TC que hubo un incumplimiento del trámite de comunicación al órgano judicial, no solo porque se rebasara el plazo máximo de las veinticuatro horas, sino también porque no se llevó a cabo por quien tenía que hacerlo; considera que las trabajadoras sociales del equipo de internamientos involuntarios del Samur social que habían trasladado a la recurrente a dicha residencia, no pueden sustituir al director del centro en cuanto a cumplimentar la comunicación al juez. Reprocha el TC que el Juzgado considerara suficiente tal comunicación. Finalmente, al no constar que la recurrente se hallara dada de alta, se acordó su libertad inmediata.

También sobre este tema, la Sala Segunda, en la STC 22/2016, de 15 de febrero, analizó el recurso de amparo planteado por el Ministerio Fiscal contra la resolución judicial que acordó ratificar la medida de internamiento de una paciente en un centro hospitalario, por razón de trastorno psíquico, al amparo del art. 763 LEC. A dicha resolución judicial le atribuía, como queja principal, la vulneración del derecho a la libertad personal y la del derecho a un proceso con todas las garantías, al haberse omitido las garantía esencial de asegurar a la afectada la defensa letrada antes de resolver el Juzgado sobre la ratificación del internamiento. En relación con esta queja señala el TC que durante el acto de exploración judicial, la recurrente manifestó el deseo de que se le nombrara un abogado para su defensa y, aunque se proveyó inicialmente a esa solicitud acordando el Juzgado dirigir comunicación al correspondiente Colegio de Abogados para los respectivos nombramientos, antes de recibir respuesta dictó Auto de ratificación del internamiento pese a que tenía margen hasta el día siguiente para resolver. La negación de esta intervención de su representante procesal y defensor produjo, pues, la vulneración del derecho a la asistencia jurídica, que en el ámbito de las garantías del proceso de internamiento involuntario del art. 763 LEC se reconduce a una lesión del derecho a la libertad del art. 17.1 CE, del que resulta ser titular la paciente ingresada.

También la STC 34/2016 (Salsa Segunda), de 29 de febrero, abordó este tipo de internamientos. Nuevamente, se interpuso un recurso de amparo por el Ministerio Fiscal contra una resolución judicial que desestimó la solicitud de internamiento no voluntario de una paciente al considerar que se había vulnerado el derecho a la libertad (art. 17.1 CE) de la afectada. Los órganos judiciales habían entendido, sin negar que se trataba de una situación privativa de libertad que debe ser sujeta a control judicial, que la autorización co- 
rrespondiente debería instarse dentro del proceso para la declaración de incapacidad de los arts. 756 a 762 LEC, pero no por los trámites del procedimiento del art. 763 LEC, pues faltaba el requisito de la «urgencia» que exige esta última norma. Recuerda el Tribunal, en relación con la posibilidad de «regularización" de situaciones consumadas de internamientos de personas por trastorno psíquico, que la decisión de internamiento solo puede ser acordada judicialmente. Explica que, en relación con el internamiento involuntario urgente por trastorno psíquico, el legislador permite, excepcionalmente y por razones de urgencia, que el responsable de un centro médico pueda ordenar el internamiento de una persona por razón de trastorno psíquico, con la obligación de comunicarlo al órgano judicial competente para que provea a la ratificación o no de la medida. En el caso analizado ${ }^{33}$, concluye el TC afirmando que no resulta posible hablar de la «regularización» de un internamiento involuntario que se prolonga durante días, semanas o meses sin autorización del juez, sea en un hospital, centro socio sanitario o en su caso residencia geriátrica. De las dos modalidades de control judicial que establece el art. 763 LEC, la Fiscalía optó por solicitar el internamiento urgente, al poner de manifiesto en su escrito que la paciente ya se encontraba en el centro sociosanitario al tiempo de formalizarse la solicitud ante el Juzgado. Las resoluciones judiciales impugnadas no cuestionaban la concurrencia de la existencia de un trastorno psíquico con entidad suficiente para justificar una medida de internamiento, pero negaban que se diera la «urgencia» requerida para el internamiento. El TC consideró que no puede reputarse urgente la autorización del internamiento porque este se haya prolongado durante meses sin control judicial y se pretenda evitar así que tal situación continúe; no obstante, tras hacer uso del trámite previsto en el art. 84 LOTC, estimó que la constatación por los Autos impugnados de que no se había instado el proceso adecuado para tutelar la situación de la paciente, no impedía sino que, justamente al contrario, obligaba a que se diera una solución que pusiera fin a la ilicitud de su internamiento; por ello, consideró que los órganos judiciales debieron proveer la apertura del proceso de incapacitación. Con el poder ex officio que les concede el art. 762.1 LEC, con base en los informes médicos de los que se disponía, debieron acordar la adopción inmediata del internamiento como

33 Considera el Tribunal que la situación de la afectada coincide con el de otras muchas personas que debido a su edad avanzada sufren una enfermedad neurodegenerativa y se encuentran recluidas en una residencia sin poder salir de ella, como medida de prevención, y afirma que estos centros tienen bajo su cargo a personas que están privadas de su libertad ambulatoria y lo están, con cierta frecuencia en la práctica, sin ningún conocimiento ni autorización de la autoridad judicial. 
medida cautelar, procediendo por su parte el Ministerio Fiscal a promover la correspondiente demanda de incapacitación de la afectada. En definitiva, declaró lesionado el art. $17 \mathrm{CE}$, por no haberse adoptado ninguna decisión sobre la situación personal de la internada.

3. Sobre el discutido derecho a la intimidad familiar, la Sala Primera, en la STC 11/2016, de 1 de febrero, dicta una sentencia que pudiera considerarse el caso perfecto para elevar al Pleno un asunto tan discutible como es el alcance, incluso su propia existencia, de tal derecho en nuestra jurisprudencia constitucional. De hecho, la Sentencia cuenta con tres votos particulares - dos en contra y otro concurrente- , aunque todos ellos muestran serias dudas del reconocimiento del derecho a la intimidad familiar. La demanda de amparo impugnaba el Auto que denegó la licencia de incineración de los restos resultantes del aborto padecido por la actora. Consideraba la recurrente que la denegación del permiso solicitado vulneró el art. 16.1 CE, por carecer de todo fundamento legal, ya que los valores y creencias de la demandante no podían merecer menos respeto que aquellos que pudieran adjetivarse como «religiosos» $\mathrm{O}$ «confesionales» y porque no había razón alguna de orden público que pudiera justificar la denegación de la entrega solicitada. Alegaba también el principio de igualdad y la proscripción de discriminación, porque en un asunto anterior, el mismo Juzgado accedió entregar a otra madre los restos humanos de su hijo, atendiendo a la religión de la solicitante (musulmana), el tipo de aborto (espontáneo) y el peso del feto. La demanda razonaba igualmente la lesión del derecho a la intimidad familiar (art. 18.1 CE) a través de la jurisprudencia del TEDH. Explica el TC que no hay precedente constitucional sobre casos análogos - lo que reforzaría la idea de que el asunto debió ser abordado por el Pleno del Tribunal-, por lo que para su argumentación recurre a la jurisprudencia del $\mathrm{TEDH}$, que ha resuelto asuntos similares en un sentido favorable al reconocimiento del derecho a disponer de los restos humanos para su enterramiento como contenido del derecho al respeto de la vida privada y familiar (art. 8 $\mathrm{CEDH})$. Tras un pormenorizado recorrido por los pronunciamientos del $\mathrm{TEDH}$, afirma, sin mayor explicación, que la pretensión de la demandante que da origen a las resoluciones impugnadas se incardina en el ámbito del derecho a la intimidad personal y familiar reconocido en el art. 18.1 CE. Ahora bien, continúa afirmando que, como todo derecho fundamental, también este admite restricciones que respondan a "un fin constitucionalmente legítimo" y que sean necesarias y adecuadas "para alcanzar dicho objetivo». Señala que es necesario constatar el cumplimiento de cuatro requisitos o condiciones que, según reiterada doctrina, se erigen en canon de control para estos casos: si la medida restrictiva disponía de la correspondiente cobertura legal; si era susceptible de conseguir el objetivo propuesto; si era necesaria y, finalmente, si era 
proporcionada en sentido estricto. Comienza su razonamiento reconociendo que los órganos judiciales tropezaban con la dificultad de la falta de una regulación clara en esta materia: no contaban con previsiones específicas que determinaran si puede la administración hospitalaria entregar por sí los restos humanos sin necesidad de autorización judicial o, en la hipótesis de que sea necesario el permiso judicial de incineración, si este presupone o no la inscripción en el legajo de criaturas abortivas del registro civil. Partiendo de la interpretación de que el permiso judicial es preceptivo y de que su obtención presupone la inscripción registral, los Autos impugnados justificaron la imposibilidad de practicar esa inscripción ( $y$, por ende, la de acceder a lo solicitado) en el art. 45 de la Ley del registro civil ${ }^{34}$. Tanto el Juzgado como la Audiencia Provincial derivaron de la obligación de inscribir criaturas abortivas de más de 180 días, la prohibición de inscribir las de menor tiempo, aunque ello suponga que los padres no puedan asistir a la incineración de su hijo no nato en una ceremonia funeraria íntima o familiar. Sin embargo, estima el TC que, de la imposición de un deber de inscripción a partir de un determinado tiempo de gestación, no cabe deducir extensivamente la prohibición de entrega para su enterramiento o incineración de criaturas abortivas de menor tiempo. De ello deduce el TC que las resoluciones judiciales impugnadas han restringido el derecho a que la vida personal y familiar sea respetada (art. 18.1 CE), sin esgrimir una norma verdaderamente habilitante y, por tanto, sin la suficiente cobertura legal. Además señala que, en cualquier caso, de las actuaciones no resulta impedimento alguno de orden público general o sanitario que pudiera justificar la injerencia en el derecho de la demandante a decidir sobre el enterramiento o incineración de su criatura abortiva ex art. 18.1 CE. Por otra parte, de las actuaciones se deriva igualmente la inexistencia de riesgos para la salud pública: constaba incluso un informe médico-forense según el cual «lo que se solicita no tiene ningún impedimento médico-legal ni sanitario». En conclusión, afirma el TC que las resoluciones impugnadas han vulnerado el derecho fundamental a la intimidad personal y familiar de la actora, por no esgrimir normas que pudieran dar cobertura jurídica suficiente a su decisión e imponer un sacrificio desproporcionado, «sin que se vislumbren bienes constitucionales cuya preservación justifique la denegación del permiso de incineración solicitado». Como antes se apuntó, la importante discrepancia sobre el asunto debería haber conllevado la elevación al Pleno del TC del recurso, más aún tras afirmar el presidente, señor Pérez de los Cobos, en su voto particular, que

34 Tal artículo dispone: «Las personas obligadas a declarar o dar el parte de nacimiento están también obligadas a comunicar en la misma forma el alumbramiento de las criaturas abortivas de más de ciento ochenta días de vida fetal, aproximadamente». 
nuestra Constitución no reconoce un «derecho a la vida familiar» en los mismos términos en que la jurisprudencia del Tribunal Europeo de Derechos Humanos ha interpretado el art. 8.1 CEDH (SSTC 236/2007, de 7 de noviembre, FJ 11, y 60/2010, de 7 de octubre, FJ 8), y que es jurisprudencia constitucional reiterada [...] que el «derecho a la vida familiar» derivado de los arts. 8.1 CEDH y 7 de la Carta de los derechos fundamentales de la Unión Europea no es una de las dimensiones comprendidas en el derecho a la intimidad familiar ex art. 18.1 CE (STC 186/2013, de 4 de noviembre, FJ 7).

También con el art. 18 CE en juego, en concreto con su apartado cuarto, el Pleno del Tribunal en la STC 39/2016, de 3 de marzo, ha modificado la doctrina anterior sobre el tema, establecida en la STC 29/2013 (Sala Primera), de 11 de febrero. La demandante de amparo fue despedida por transgresión de la buena fe contractual. Detectadas irregularidades en la empresa, se instaló una cámara de videovigilancia en la tienda donde prestaba sus servicios la demandante y se contrató su irregular actuación. La cámara se instaló sin comunicación a los trabajadores, si bien en el escaparate del establecimiento, en un lugar visible, se colocó el distintivo informativo de su existencia. El núcleo de la demanda de amparo era la lesión del art. 18.4 CE, derecho a la protección de datos. Recuerda el TC que ya en la STC 292/2000 (Pleno), de 30 de noviembre, se puso de manifiesto que el contenido del derecho fundamental a la protección de datos consiste en un poder de disposición y de control sobre los datos personales; por ello, los elementos característicos de tal derecho fundamental son el derecho del afectado a consentir sobre la recogida y uso de sus datos personales y el derecho a ser informado de quién posee sus datos personales y con qué fin. El consentimiento del afectado es, por tanto, el elemento definidor del sistema de protección de datos de carácter personal. No obstante, recuerda que el art. 6.2 LOPD enumera una serie de supuestos en los que resulta posible tratar y ceder datos sin recabar el consentimiento del afectado; en concreto "cuando se refieran a las partes de un contrato o precontrato de una relación negocial, laboral o administrativa y sean necesarios para su mantenimiento o cumplimiento». De ello deduce el TC que en el ámbito laboral el consentimiento del trabajador pasa, como regla general, a un segundo plano, pues se entiende implícito en la relación negocial, siempre que el tratamiento de datos de carácter personal sea necesario para el mantenimiento y el cumplimiento del contrato firmado por las partes. Ahora bien, advierte el TC de que, aunque no sea necesario el consentimiento, el deber de información sigue existiendo, pues este deber permite al afectado ejercer los derechos de acceso, rectificación, cancelación y oposición. El TC considera que, en cualquier caso, el incumplimiento del deber de requerir el consentimiento del afectado para el tratamiento de datos o del deber de información 
previa solo supondrá una vulneración del derecho fundamental a la protección de datos tras una ponderación de la proporcionalidad de la medida adoptada. Aplicando estos razonamientos al tratamiento de datos obtenidos por la instalación de cámaras de video vigilancia en el lugar de trabajo, concluye el TC que «el empresario no necesita el consentimiento expreso del trabajador para el tratamiento de las imágenes que han sido obtenidas a través de las cámaras instaladas en la empresa con la finalidad de seguridad o control laboral, ya que se trata de una medida dirigida a controlar el cumplimiento de la relación laboral y es conforme con el art. 20.3 del texto refundido de la Ley del estatuto de los trabajadores». El consentimiento se entiende implícito en la propia aceptación del contrato que implica reconocimiento del poder de dirección del empresario. En cuanto al deber de información, considera el TC que se debe valorar la observancia o no del principio de proporcionalidad. Debe ponderarse el derecho a la protección de datos y sus eventuales limitaciones justificadas en el cumplimiento de las obligaciones laborales y las correlativas facultades empresariales de vigilancia y control reconocidas en el art. 20.3 del texto refundido de la Ley del Estatuto de los Trabajadores, en conexión con los arts. 33 y $38 \mathrm{CE}$. La recurrente en amparo consideraba vulnerado el art. 18.4 CE porque no había sido informada previamente de la instalación de cámaras de videovigilancia en el puesto de trabajo. Según consta en los hechos probados de las resoluciones recurridas, la cámara estaba situada en el lugar donde se desarrollaba la prestación laboral, enfocando directamente a la caja, y en el escaparate del establecimiento, en un lugar visible, se colocó el distintivo informativo exigido por la instrucción 1/2006, de 8 de noviembre, de la Agencia Española de Protección de Datos. Considera el TC que la colocación del correspondiente distintivo en el escaparate de la tienda donde prestaba sus servicios la recurrente en amparo, supone que la demandante podía conocer la existencia de las cámaras y la finalidad para la que habían sido instaladas. Es más, según el TC

se ha cumplido en este caso con la obligación de información previa, pues basta a estos efectos con el cumplimiento de los requisitos específicos de información a través del distintivo, de acuerdo con la instrucción 1/2006. El trabajador conocía que en la empresa se había instalado un sistema de control por videovigilancia, sin que haya que especificar, más allá de la mera vigilancia, la finalidad exacta que se le ha asignado a ese control.

Lo importante, según el TC, será determinar si el dato obtenido se ha utilizado para la finalidad de control de la relación laboral o para una finalidad ajena al cumplimiento del contrato, porque solo si la finalidad del tratamiento de datos no guarda relación directa con el mantenimiento, desarrollo o con- 
trol de la relación contractual, el empresario estaría obligado a solicitar el consentimiento de los trabajadores afectados. En este caso, el sistema de video vigilancia captó la apropiación de efectivo de la caja de la tienda por parte de la recurrente, que por este motivo fue despedida disciplinariamente. Por tanto, el dato recogido fue utilizado para el control de la relación laboral. En consecuencia, teniendo la trabajadora información previa de la instalación de las cámaras de video vigilancia a través del correspondiente distintivo informativo, y habiendo sido tratadas las imágenes captadas para el control de la relación laboral, no puede entenderse vulnerado el art. 18.4 CE. Finalmente, descarta el Tribunal lesión alguna del derecho a la intimidad de la recurrente (art. 18.1 CE), al constatar que la medida analizada es idónea, necesaria y equilibrada. La Sentencia cuenta con un voto particular del magistrado señor Valdés Dal-Ré al que se adhiere la magistrada Adela Asua Batarrita, y otro voto discrepante del magistrado Xiol Ríos.

4. Sobre el art. 23 CE, la STC 10/2016 (Sala Primera), de 1 de febrero $^{35}$, recuperando una jurisprudencia que parecía olvidada, abordó el examen del acuerdo de la Mesa de la Asamblea extremeña por el que se inadmitió a trámite la propuesta de Ley de Defensa de la Sanidad Pública, y el posterior acuerdo de ese mismo órgano que desestimó el recurso de reconsideración. Se aducía que tales actos vulneraron el derecho de los miembros del grupo parlamentario que presentó dicha propuesta a acceder en condiciones de igualdad a las funciones y cargos públicos con los requisitos que señalen las leyes (art. 23.2 CE), en relación con el derecho de los ciudadanos a participar en los asuntos públicos. Recuerda el TC que, dado que las decisiones de inadmisión de las propuestas de ley pueden implicar una limitación del derecho a ejercer la función parlamentaria y con él del derecho de participación ciudadana, se ha exigido que estas estén formal y materialmente motivadas. En relación con el ejercicio de la iniciativa legislativa parlamentaria, el TC ha señalado que a la mesa le compete verificar si la iniciativa cumple con los requisitos formales exigidos por la norma parlamentaria, pero dicho examen no debe suplantar las funciones que le corresponden a la Asamblea legislativa, y que gozan de relevancia constitucional cuando consisten, precisamente, en ejercer la función legislativa por los representantes de los ciudadanos. Puesto que la participación en el ejercicio de dicha función y el desempeño de los derechos y facultades que la acompañan, entre los que indudablemente debe contarse con el derecho a la iniciativa legislativa, constituyen una manifestación constitucionalmente relevante del ius in officium del representante, toda decisión de la

35 Comentada asimismo supra, pp. 309-312. 
Mesa sobre la admisibilidad y tramitación de una iniciativa legislativa promovida por un representante de los ciudadanos afecta a su derecho al libre e igual ejercicio de su cargo público, de forma que, perturbado o coartado este, se perturba y coarta la participación de los ciudadanos en los asuntos públicos, infringiendo, así pues, el art. 23.1 y 2 CE. Por tanto, como norma general, las Mesas han de abstenerse de realizar un pretendido juicio de constitucionalidad acerca de los contenidos de las propuestas de ley, admitiendo a trámite cuando se cumplan todas las formalidades reglamentariamente establecidas. Excepcionalmente, se admite que se pueda rechazar una propuesta de ley cuando sea contraria a la Constitución o ajena a las competencias atribuidas al ordenamiento en cuyo seno pretende integrarse, exigiéndose para ello que la contradicción a Derecho o la inconstitucionalidad de la proposición sean palmarias y evidentes. Pero esa condición no concurre en el caso analizado, según el TC. Este criterio, sobre la posibilidad de que la mesa realice un análisis de la constitucionalidad de la propuesta, fue utilizado por el Tribunal en su antigua jurisprudencia, pero abandonado en la más reciente; ahora parece recuperarse la jurisprudencia inicial.

También sobre el art. $23 \mathrm{CE}$, en relación con el art. $25 \mathrm{CE}$, versa la STC 78/2016 (Sala Primera), de 25 de abril. Se impugnaba el acuerdo del presidente de la Asamblea de Madrid por el que se decidió la expulsión de la recurrente de la sesión ordinaria que se estaba celebrando, así como la suspensión temporal de su condición de diputada en activo por plazo de un mes. Destacando los matices de las garantías del art. $25 \mathrm{CE}$ dentro del procedimiento sancionador parlamentario, analiza el acuerdo sancionador del presidente de la Asamblea de Madrid, que se apoya en lo previsto con carácter general en el art. 33 Reglamento de la Asamblea de Madrid $(\mathrm{RAM})^{36}$. Sin perjuicio de considerar que la imposición de la sanción citada apareció formalmente motivada ${ }^{37}$, estima que

36 Dicho precepto dispone: «El diputado que, dentro del recinto parlamentario, en sesión o fuera de ella, atentare de modo grave contra la disciplina, el orden o la cortesía parlamentaria, provocando desorden con su conducta de obra o de palabra [...] será sancionado por el presidente con la inmediata expulsión del recinto parlamentario. El presidente, además, le suspenderá temporalmente en sus derechos y deberes, por plazo de un mes, sin perjuicio de que el Pleno, de conformidad con lo dispuesto en el art. 35.1.e) y 2 del presente Reglamento, pueda revisar la sanción, ampliando su duración».

37 En el escrito de contestación del presidente de la cámara a la petición de reconsideración se señala que «no fue el uso de un determinado calificativo injurioso lo que motivó la expulsión de la diputada, sino un conjunto de afirmaciones y actitudes reiteradas, que no pueden tener cabida en sede parlamentaria y que de hecho encajan perfectamente en la sanción prevista en el art. 33 del Reglamento». 
la conducta típica que se describe en el art. 33 RAM, consiste en atentar de modo grave contra la disciplina, el orden o la cortesía parlamentaria, provocando desorden con su conducta, de obra o de palabra y, de acuerdo con sus términos literales, ha de entenderse que tal desorden debe alcanzar una cierta entidad, impidiendo la continuación normal de la sesión de la que se trate, hasta el punto de que se requiera, para reestablecer el orden, «la inmediata expulsión del recinto parlamentario» del diputado que lo causare. Pues bien, analizando los hechos, el TC constata que la diputada recurrente llamó «corrupto» al presidente del Gobierno regional, y que lo vinculó a una determinada trama delictiva. Tales expresiones fueron consideradas por la Presidencia de la cámara suficientes para ser merecedoras de sucesivas llamadas al orden, que se repitieron en tres ocasiones, instando a la diputada para que cejara en su actitud y, posteriormente, para que retirara sus palabras, cosa que no hizo. Hasta aquí, nada puede objetarse a la actuación de la Presidencia de la Asamblea, que advirtió a la diputada de que podría ser expulsada si persistía en su comportamiento y procedió, tras la tercera llamada al orden, a retirarle la palabra definitivamente, una decisión frente a lo que la recurrente se aquietó, lo que hizo innecesario que el presidente de la Asamblea procediera a adoptar las medidas de «inmediata expulsión del salón de sesiones» y "prohibición de asistencia al resto de la correspondiente sesión». Nada más serle retirada la palabra a la recurrente, se dio paso a la tramitación de las siguientes preguntas de contestación oral en Pleno, lo que tuvo lugar con normalidad. Y es solo al terminar la tramitación de estas cuando el presidente de la cámara hizo un inciso antes de dar paso a la discusión del segundo punto del orden del día y anunció en la cámara que iba a aplicar a la recurrente lo dispuesto en el art. 33 RAM, conminándola para que abandonara la sala de manera inmediata. Es en este punto, considera el TC, que el acuerdo sancionador vulneró el principio de legalidad del art. 25.1 $\mathrm{CE}$, desde la perspectiva de la garantía material de tipicidad. En primer lugar, porque la sanción se produce una vez que la alteración del orden había cesado y se había procedido ya a debatir de otros asuntos con normalidad, por lo que su tramitación culminó sin incidentes; por tanto, la medida sancionadora careció de la continuidad temporal que exige el art. 33 RAM, en el que se requiere que la sanción se aplique a hechos recién acaecidos. La sanción, además, comportó un trato desigual de la demandante respecto a otros diputados de la misma Asamblea, ya que en circunstancias similares que tuvieron lugar en una sesión plenaria muy cercana en el tiempo a aquella en la que se produjeron los hechos ahora enjuiciados, a algunos de esos representantes se les expulsó de forma inmediata del recinto parlamentario y a otros no, pero ninguno de ellos fue suspendido de su cargo durante un mes. En consecuencia, la resolución impugnada ha conculcado el derecho fundamental que a la actora le reconoce el art. 25.1 CE. Esta lesión implica, asimismo, la violación del derecho garan- 
tizado por el art. 23.2 CE, pues la expulsión del recinto parlamentario, así como la suspensión temporal de la condición de diputada sin cobertura legal ha privado a la recurrente de su derecho a permanecer, sin intromisiones ni limitaciones ilegítimas y en condiciones de igualdad, en el cargo público para el que fue elegida. Comporta, a su vez, la del derecho de los electores a participar en los asuntos públicos a través de sus representantes elegidos en elecciones periódicas por sufragio universal (art. 23.1 CE).

5. La STC 65/2016 (Sala Primera), de 11 de abril, aborda, en palabras del TC, «un recurso que plantea un problema o afecta a una faceta de un derecho fundamental sobre el que no hay doctrina de este TC». Los hechos se refieren a la menor, hija de la recurrente en amparo, que fue declarada en situación de desamparo por la Consejería de Igualdad y Bienestar Social de la Junta de Andalucía; en 2007 se formuló propuesta de constitución judicial de acogimiento familiar preadoptivo; la recurrente formuló oposición que fue desestimada por Sentencia; interpuso entonces recurso de amparo, que fue inadmitido; finalmente, formuló demanda ante el TEDH, que declaró que había habido violación del art. 8 del $\mathrm{CEDH}$, al apreciar que las autoridades españolas no habían desplegado los esfuerzos adecuados y suficientes para hacer respetar el derecho de la demandante a vivir con su hija. Tras dicha Sentencia del TEDH, la recurrente formuló incidente extraordinario de nulidad de actuaciones para «ejecutar» la Sentencia del TEDH, pero fue inadmitido por Auto. En la demanda de amparo se denunciaba la vulneración del derecho fundamental a un proceso con todas las garantías (art. 24.2 CE), en relación con el art. 10.2 $\mathrm{CE}$, en conexión con el derecho fundamental a la vida y la integridad física del menor (art. $15 \mathrm{CE}$ ) y con el derecho al respeto a la vida privada y familiar. En síntesis, se alegaba la inmotivada inadmisión del incidente de nulidad de actuaciones, que ha impedido una decisión sobre el fondo de la pretensión, y se defiende la idoneidad del incidente extraordinario como vía para articular la pretensión. Recordando una vez más el TC el nuevo y esencial papel que juega el incidente de nulidad en la regulación del actual recurso de amparo, considera que en el caso concreto se perseguía - como un efecto de una Sentencia TEDH - la reapertura de un proceso concluido con resolución judicial firme. Tras recordar que tales resoluciones tienen carácter declarativo y que el CEDH no obliga a dar efecto interno a las Sentencias del TEDH mediante la anulación de la autoridad de cosa juzgada de la decisión judicial nacional, explica que ello no obsta a lo que se reclama en la demanda de amparo, que es una respuesta motivada al incidente promovido. En segundo lugar, aclara que, si bien la pretensión, al canalizarse mediante un incidente de nulidad de actuaciones el derecho fundamental comprometido sería el derecho de acceso a los recursos legalmente establecidos, el hecho de que se articulara ante el vacío le- 
gal sobre cuál debía ser el cauce procesal oportuno para la ejecución de la $\mathrm{STEDH}^{38}$, supone que, en realidad, el derecho en juego sea el acceso a la jurisdicción, sujeto al principio de interpretación pro actione. Delimitado así el objeto del recurso de amparo, lo otorga, censurando que el órgano judicial no motivara la inadmisión del incidente y, además, ignorara la regulación del incidente de nulidad tras la reforma de 2007. Reitera el TC que el órgano judicial debe «realizar una interpretación [sic] no restrictiva de los motivos de inadmisión, tramitar el incidente y motivar, en cualquier caso, suficientemente su decisión. Como se dijo en la STC 185/1990, de 15 de noviembre, FJ 5, “será preciso interpretar las normas procesales que integren alguna vía rescisoria de Sentencias firmes en el sentido más favorable para permitir la tutela en fase jurisdiccional de los derechos fundamentales" (FJ 3)»39.

38 Este déficit, ya apreciado por la STC 245/1991 (Pleno), de 16 de diciembre, FJ 5, ha sido enmendado por la Ley Orgánica 7/2015, de 21 de julio, por la que se modifica la Ley Orgánica 6/1985, de 1 de julio, del Poder Judicial, que designa a tal fin el recurso de revisión ante el TS (artículo único, tres, que añade un nuevo art. 5 bis a la Ley Orgánica del Poder Judicial). En concreto, en el orden civil, la disposición final cuarta, apartado 13, de dicha Ley Orgánica modifica el art. 510.2 LEC, en el siguiente sentido: «Asimismo se podrá interponer recurso de revisión contra una resolución judicial firme cuando el TEDH haya declarado que dicha resolución ha sido dictada en violación de alguno de los derechos reconocidos en el Convenio Europeo para la Protección de los Derechos Humanos y Libertades Fundamentales y sus Protocolos, siempre que la violación, por su naturaleza y gravedad, entrañe efectos que persistan y no puedan cesar de ningún otro modo que no sea mediante esta revisión, sin que la misma pueda perjudicar los derechos adquiridos de buena fe por terceras personas». En consonancia, se modifica el art. 511 LEC, que reconoce la legitimación activa solo al que hubiera sido demandante ante el TEDH, así como el art. 512.1 LEC, que fija el plazo de un año desde la firmeza de la Sentencia del TEDH para interponer el recurso.

39 Es importante destacar que el TC, en cuanto al incidente de nulidad, viene padeciendo un error que arrastra desde la STC 153/2012 (Sala Segunda), de 16 de julio (comentada, emntre otras, en la crónica publicada en $R E D C$, núm. 96, 2012, pp. 241 242), FJ 3, hasta la que ahora se comenta, y que consta también en las siguientes: STC 186/2015, de 21 de septiembre, FJ 2; STC 180/2015, de 7 de septiembre, FJ 2; STC 101/2015, de 25 de mayo, FJ 2; STC 204/2014, de 15 de noviembre (reseñada en REDC, núm. 103, 2015, p. 261), FJ 3; STC 4/2014, de 27 de enero, FJ 3; STC 2/3013, de 14 de enero (comentada en REDC, núm. 98, 2013, pp. 273-274), FJ 5. El error consiste en afirmar que el órgano judicial debe «realizar una interpretación no restrictiva de los motivos de inadmisión, tramitar el incidente y motivar, en cualquier caso, suficientemente su decisión", cuando, en realidad, lo que se quiere decir es lo contrario. Así se deduce de la argumentación y del propio fallo de las Sentencias que 
Sobre el derecho a la tutela judicial efectiva, destaca en este período la STC 58/2016 (Pleno), de 17 de marzo, que abordó la constitucionalidad del art. 102 bis $2 \mathrm{LJCA}^{40}$ — precepto añadido por el art. 14.45 de la Ley 13/2009, de 3 de noviembre, de reforma de la legislación procesal para la implantación de la nueva oficina judicial—, por posible vulneración del art. 24.1 CE. El Auto de planteamiento de la cuestión interna de inconstitucionalidad consideraba que el art. 102 bis 2 LJCA podría vulnerar el derecho a la tutela judicial efectiva en la medida en que excluye la posibilidad de que el decreto del secretario judicial - hoy letrados de la Administración de Justicia - que resuelve el recurso de reposición contra sus propias diligencias de ordenación, sea revisado por el juez o TC a través de un recurso directo de revisión. La Sala Segunda, proponente de la cuestión, razonaba que contra el decreto del letrado de la Administración de Justicia que desestima el recurso de reposición contra la diligencia de ordenación que señaló fecha para la vista del procedimiento abreviado contencioso-administrativo (acto que se considera lesivo del derecho fundamental a un proceso sin dilaciones indebidas en el recurso de amparo del que trae causa la presente cuestión interna) no cabe, de acuerdo con lo dispuesto en el art. 102 bis 2 LJCA, recurso alguno ante el juez o Tribunal, titular de la función jurisdiccional. Ello determinaría que en el recurso de amparo del que trae causa la cuestión

se esté recurriendo, bajo la cobertura del art. 44 LOTC, un acto de un órgano judicial que, sin embargo, no emana del titular del mismo, es decir, que no es dictado por el juez o magistrado, sino por la Secretaria Judicial de aquel, lo que ciertamente plantea una situación no solamente atípica sino problemática en cuanto a su encaje en el amparo contra actos judiciales a que se refiere el citado art. 44 LOTC $^{41}$.

se han reseñado. Solamente en una ocasión, STC 91/2015, de 11 de mayo, FJ 2, se afirmó lo que en realidad se quería decir: que el órgano judicial debe realizar una interpretación no restrictiva de las causas de admisión del incidente de nulidad.

40 Tal precepto dispone: «2. Contra el decreto resolutivo de la reposición no se dará recurso alguno, sin perjuicio de reproducir la cuestión al recurrir, si fuere procedente, la resolución definitiva. Cabrá un recurso directo de revisión contra los decretos por los que se ponga fin al procedimiento o impidan su continuación. Dicho recurso carecerá de efectos suspensivos sin que, en ningún caso, proceda actuar en sentido contrario a lo que se hubiese resuelto. Cabrá interponer igualmente un recurso directo de revisión contra los decretos en aquellos casos en que expresamente se prevea».

41 Este precepto «permite la interposición del recurso contra las violaciones de los derechos y libertades protegibles en amparo "que tuvieran su origen inmediato y directo en un acto u omisión de un órgano judicial”, expresión esta última que ha de enten- 
En primer término, considera el TC que no puede merecer en principio reproche de inconstitucionalidad la opción tomada por el legislador, en el marco del modelo de oficina judicial, por la que la toma de decisiones en el proceso se distribuye entre jueces y magistrados, por un lado, y letrados de la Administración de Justicia, por otro ${ }^{42}$. El problema que se plantea el TC se centra en que no es descartable la eventualidad de que existan supuestos en los que la decisión del letrado de la Administración de Justicia excluida por el legislador del recurso de revisión ante el juez o TC, concierna a cuestiones relevantes en el marco del proceso, que atañen a la función jurisdiccional reservada en exclusiva a jueces y magistrados, a quienes compete dispensar la tutela judicial efectiva sin indefensión que a todos garantiza el art. 24.1 CE. Así sucede en el supuesto del señalamiento por el letrado de la Administración de Justicia del día para la celebración de la vista en el procedimiento abreviado contencioso-administrativo. Esta decisión, una vez confirmada en reposición por el letrado, queda excluida del recurso directo de revisión ante el juez o TC, conforme a lo dispuesto en el cuestionado párrafo primero del art. 102 bis 2 LJCA, y se priva con ello al justiciable de la posibilidad de someter a la decisión última del titular del órgano judicial una cuestión que afecta a un derecho fundamental, que en el caso sería el derecho a un proceso sin dilaciones indebidas, garantizado por el art. 24.2 CE. En suma, considera el TC, el párrafo primero del art. 102 bis 2 LJCA, redactado por la Ley 13/2009 incurre en una insalvable inconstitucionalidad al crear un espacio de inmunidad jurisdiccional incompatible con el derecho fundamental a la tutela judicial efectiva y la reserva de jurisdicción a los jueces y tribunales integrantes del poder judicial. El precepto cuestionado, en cuanto que excluye del recurso judicial a determinados decretos definitivos del letrado de la Administración de Justicia (aquellos que resuelven la reposición), lesiona el derecho del justiciable a someter a la decisión última del juez o TC, a quien compete de modo exclusivo

derse referida, de conformidad con las previsiones del art. $117 \mathrm{CE}$, a los juzgados y tribunales servidos por jueces y magistrados integrados en el Poder Judicial, y a los que corresponde el ejercicio de la potestad jurisdiccional, juzgando y haciendo ejecutar lo juzgado, sin que quepa realizar una interpretación amplia de ese concepto que permita convertir en objeto del recurso de amparo todo acto procedente de cualquier sujeto que se encuentre incluido en la organización judicial. Esto es, la lesión constitucional recurrible en amparo solo podría ser atribuible a una actuación de los órganos judiciales, "que son los llamados a prestar la tutela jurisdiccional de los derechos"».

42 Se reserva a los primeros las decisiones procesales que puedan afectar a la función o potestad estrictamente jurisdiccional y se atribuye a los segundos, que asumen la dirección de la oficina judicial, aquellas funciones que no tienen carácter jurisdiccional, lo que incluye el dictado de resoluciones procesales que no tengan este carácter. 
la potestad jurisdiccional, la resolución de una cuestión que atañe a sus derechos e intereses legítimos, pudiendo afectar incluso a otro derecho fundamental: a un proceso sin dilaciones indebidas. Precisa el TC, además, que, mientras que el legislador no se pronuncie al respecto, el recurso judicial procedente frente al decreto del letrado de la Administración de Justicia resolutivo de la reposición ha de ser el directo de revisión al que se refiere el propio art. 102 bis 2 LJCA.

6. Sobre el derecho a la huelga (art. 28 CE), en la STC 45/2016 (Sala Segunda), de 14 de marzo, la demandante - personal estatutario con categoría de facultativa especialista de área de neumología - impugnó las resoluciones de la dirección médica del Hospital Universitario Central de Asturias que desestimaron su petición de ser sustituida en su designación como personal asignado a cubrir los servicios mínimos en las jornadas de huelga, en el supuesto de que dichos servicios pudieran ser cubiertos por personal de su misma categoría y servicio que decidiera no sumarse a la convocatoria de paro. Para la demandante de amparo, las resoluciones recurridas vulneraron su derecho fundamental a la huelga. Recuerda el TC que la principal técnica que viene utilizándose para garantizar el mantenimiento de los servicios esenciales durante una huelga es la de la fijación de los servicios mínimos que los trabajadores deben cumplir. En el supuesto enjuiciado, la decisión gubernativa de fijación de servicios mínimos concretó que, dentro del Hospital Universitario Central de Asturias, la prestación de servicios mínimos en la unidad de neumología a la que pertenece la recurrente se realizaría por un facultativo en turno de mañana. Reconoce el TC que la resolución de fijación de los servicios mínimos restringe de forma inicial y directa el derecho a la huelga de los convocados, en aras al fin legítimo de garantizar el mantenimiento de los servicios esenciales de la comunidad. Destaca la Sentencia que la recurrente manifestó, antes de que se inicie la jornada de huelga, que deseaba ejercer su derecho fundamental a la huelga en el supuesto de que los mínimos pudieran ser cubiertos por personal de su misma categoría y servicio que decidan no hacer huelga. Como respuesta, se motivó la denegación en que tal cambio dificultaría o impediría la observancia de los servicios mínimos precisos para garantizar el cumplimiento del servicio público esencial encomendado a esta institución ${ }^{43}$. Subraya el TC que la exigencia constitucional de garantizar el mante-

43 Con carácter inicial advierte el TC, aun cuando las respectivas demandas presentadas en la jurisdicción ordinaria y en el recurso de amparo insisten en que la pretensión de la recurrente causante del litigio era la de ser relevada de la realización de servicios mínimos una vez comenzadas las jornadas de huelga para las que había sido designa- 
nimiento de los servicios esenciales requiere que la designación de los trabajadores encargados de su cumplimiento se realice con carácter previo al comienzo de las jornadas de huelga, a fin de asegurar que exista un número de trabajadores suficientes que puedan llevar a cabo tales servicios. Recuerda, además, que el derecho de huelga es un derecho atribuido a los trabajadores uti singuli, de modo que a cada uno de ellos corresponde el derecho de sumarse o no a las huelgas declaradas, una decisión esta que pueden adoptar tanto en cualquier momento anterior a su inicio como también durante su transcurso. En consecuencia, ante la posible interpretación de la solicitud de la recurrente como requerimiento para que la sustitución se llevara a cabo antes de iniciarse las jornadas de huelga afectadas, la doctrina sentada en la STC 123/1990 (Sala Segunda), de 2 de julio, proporciona acomodo a la denegación comunicada por la dirección médica del hospital, pues, al margen de la escasa antelación con que se efectuó la petición de cambio (la víspera de cada una de dichas jornadas de huelga), afirma que resulta evidente que no existía ningún medio que permitiese a la dirección de la entidad conocer de antemano quiénes no iban a sumarse a la huelga en los días para los que se solicitaba el cambio. De este modo, el imperativo de asegurar la prestación de los servicios esenciales, máxime si cabe en atención a la trascendencia de los bienes protegidos en un ámbito como el de la sanidad, dota de legitimidad a la respuesta denegatoria examinada. A la misma conclusión llega el TC aun cuando se interpretase, como pretendía la recurrente, que su solicitud hubiera requerido la sustitución para el supuesto de que, ya iniciadas las jornadas de huelga y personada al comienzo de estas, se hubiere constatado que los servicios mínimos fijados podían ser cubiertos por personal de su misma categoría y servicio que hubiera decidido no hacer huelga. Al respecto, señala el TC, en virtud del mencionado carácter uti singuli del derecho de huelga, en principio nada impide que un trabajador no designado para el mantenimiento de servicios esenciales pueda decantarse por desempeñar su trabajo al comienzo de la huelga y, con posterioridad, durante su desarrollo, cambie su criterio y decida sumarse a la misma, tras haber llegado a tal convicción, ya sea por reflexión personal, ya por otras vías como la propia acción informativa de los piquetes. Así pues, el derecho a la huelga de los trabajadores designados para prestar servicios mínimos no solo puede quedar limitado por la exigencia constitucional de garan-

da, lo cierto es que ya en la primera resolución judicial se ponía de relieve el carácter ambiguo del texto de la solicitud presentada ante la dirección médica del hospital, cuyo tenor también permitía entender que lo requerido por la facultativa era ser sustituida antes de iniciarse las referidas jornadas de huelga. Ante esta situación, analiza el TC ambas hipótesis. 
tizar el mantenimiento de los servicios esenciales — que prima sobre aquel—, sino que, además, también ha de conciliarse con el respeto al derecho de huelga de los trabajadores no designados y su consiguiente facultad de sumarse a la misma en cualquier momento de su transcurso.

Sobre la libertad sindical (art. 28 CE), la Sala Segunda, en la STC 64/2016, de 11 de abril, analiza la denuncia de la supuesta lesión de tal libertad, por haber sido impedidos los demandantes para el ejercicio de la actividad representativa como expresión de su actividad sindical. Los recurrentes en amparo prestaban servicios para una empresa con la categoría de auxiliares de almacén en un determinado centro de trabajo; fueron elegidos miembros del comité de empresa en las elecciones celebradas en 2011. Con posterioridad, la empresa demandada comunicó al Comité de empresa que la actividad que se desarrollaba en el centro de trabajo se trasladaría a otro centro de trabajo diferente - siendo trasladados los miembros del comité de empresa del primer centro de trabajo al segundo- - El problema constitucional planteado consistía en determinar si procede el mantenimiento de la condición representativa obtenida en el centro de origen en casos de representación unitaria sindicalizada y traslado de trabajadores, sin transmisión de la titularidad, a otra unidad productiva de la misma empresa que no cuenta con representación legal constituida. Analiza las resoluciones judiciales impugnadas, que consideraron que la decisión empresarial vendría a encontrar soporte en que el mantenimiento de la condición de miembro del comité de empresa requiere de la subsistencia del centro de trabajo para el que se fue elegido, por ello, desaparecido el centro de trabajo y trasladados los trabajadores a otros distintos, no pervive la condición de representante legal de los mismos. Considera el TC que no existe una previsión legal o convencional que garantice el mantenimiento de la condición de representante legal en casos como el enjuiciado y que no puede, por consiguiente, considerarse que la supresión de esa condición en esos concretos supuestos contraríe un derecho atribuido por normas legales o convencionales. La Sentencia cuenta con un voto particular que formula el magistrado señor Valdés Dal-Ré, al que se adhiere la magistrada señora Asua Batarrita.

En la Sentencia 69/2016, de 14 de abril, el Pleno analizó la condena al demandante de amparo al abono de una cantidad en concepto de indemnización por culpa extracontractual por los daños personales y materiales que se ocasionaron al titular de un pub como consecuencia de la acción de un piquete informativo durante una jornada de huelga general. La sentencia impugnada consideraba que las lesiones fueron fruto de la agresión llevada a cabo por integrantes indeterminados del piquete, por lo que se imputó la responsabilidad civil al recurrente, en su condición de líder de dicho piquete. Por otra parte, en cuanto a los daños materiales por lucro cesante derivados del cierre del local motivado por la actuación del piquete la Sentencia recu- 
rrida entendía que la responsabilidad del demandante de amparo le era imputable por un hecho propio. Recordando el TC que el derecho de huelga incluye el derecho de difusión e información sobre esta, pero no tutela la coacción o ejercer actos de violencia para perseguir sus fines, declara que, desde una perspectiva objetiva o material, las conductas que dieron origen a la condena por responsabilidad civil cuestionada — básicamente, agresión física e insultos dirigidos al cierre de un local de trabajo - no pueden considerarse incluidas en el derecho fundamental a la huelga, situándose extramuros de este y pudiendo generar responsabilidad civil. Subraya el TC que la fijación de los criterios de imputación de la responsabilidad civil y la determinación de esta constituyen competencias propias de los tribunales ordinarios, sin perjuicio de su competencia para revisar su decisión, a los solos efectos de valorar si la misma tiene o puede tener un efecto lesivo del contenido del derecho fundamental a la huelga. Por lo que se refiere a la indemnización impuesta por los daños personales, la Sentencia impugnada consideró indiscutido que el titular del pub fue agredido por integrantes indeterminados del piquete informativo, no identificados por la policía; nos encontramos, dice el TC, ante un supuesto de imputación directa de responsabilidad civil a quien actúa como líder o cabecilla de un piquete, sin que ni siquiera en la fundamentación jurídica de la sentencia se aluda a una eventual conexión entre la imputación de la responsabilidad al recurrente y su vinculación con uno de los sindicatos convocantes de la huelga. Por tanto, resulta lesiva de su derecho a la huelga imputar al líder del piquete la responsabilidad civil por daños personales, condenándosele al pago de una indemnización como consecuencia de un acto de violencia física realizado por terceros, sin que se precisen en la sentencia datos fácticos concretos y acreditados sobre el alcance de la actuación del recurrente en el momento exacto de la agresión. Distinta valoración le merece al TC la imputación de la responsabilidad civil por daños materiales, en cuya virtud se impone al recurrente el pago de una indemnización por el lucro cesante derivado del cierre del local. En este caso, la sentencia recurrida afirmaba que la obligación del demandante de amparo de resarcir tales daños materiales es consecuencia de acto propio, infiriéndose de su argumentación la conexión entre el comportamiento del recurrente y el cierre del pub. Es el clima de intimidación, en el contexto de un piquete masivo violento liderado y dirigido por el demandante, el que la sentencia recurrida valora para imputar la responsabilidad, lo que no puede considerarse lesivo del derecho a la huelga reconocido en el art. 28.2 CE. La Sentencia cuenta con dos votos discrepantes ${ }^{44}$.

44 Carlos Ortega Carballo. 